\title{
Current Progress on Marine Microplastics Pollution Research: A Review on Pollution Occurrence, Detection, and Environmental Effects
}

\author{
Fei-Fei Liu *, Su-Chun Wang, Zhi-Lin Zhu and Guang-Zhou Liu
}

Institute of Marine Science and Technology, Shandong University, Qingdao 266237, China; suchunw@163.com (S.-C.W.); zhuzhilinsdu@163.com (Z.-L.Z.); liuguangzhou@sdu.edu.cn (G.-Z.L.)

* Correspondence: liufeifei@sdu.edu.cn

check for

updates

Citation: Liu, F.-F.; Wang, S.-C.;

Zhu, Z.-L.; Liu, G.-Z. Current

Progress on Marine Microplastics

Pollution Research: A Review on

Pollution Occurrence, Detection, and Environmental Effects. Water 2021, 13, 1713. https://doi.org/ $10.3390 /$ w13121713

Academic Editors: Ines Martins, Irene Martins and Joana Raimundo

Received: 9 May 2021

Accepted: 16 June 2021

Published: 21 June 2021

Publisher's Note: MDPI stays neutral with regard to jurisdictional claims in published maps and institutional affiliations.

Copyright: (C) 2021 by the authors. Licensee MDPI, Basel, Switzerland. This article is an open access article distributed under the terms and conditions of the Creative Commons Attribution (CC BY) license (https:/ / creativecommons.org/licenses/by/ $4.0 /)$.

\begin{abstract}
Recently, microplastics pollution has attracted much attention in the environmental field, as researchers have found traces of microplastics in both marine and terrestrial ecological environments. Here, we reviewed and discussed the current progress on microplastics pollution in the marine environment from three main aspects including their identification and qualification methods, source and distribution, and fate and toxicity in a marine ecosystem. Microplastics in the marine environment originate from a variety of sources and distribute broadly all around the world, but their quantitative information is still lacking. Up to now, there have been no adequate and standard methods to identify and quantify the various types of microplastics, which need to be developed and unified. The fate of microplastics in the environment is particularly important as they may be transferred or accumulated in the biological chain. Meanwhile, microplastics may have a high adsorption capacity to pollutants, which is the basic research to further study their fate and joint toxicity in the environment. Therefore, all the findings are expected to fill the knowledge gaps in microplastics pollution and promote the development of relative regulations.
\end{abstract}

Keywords: microplastics; marine environment; contaminants; toxicity; adsorption

\section{Introduction}

Plastics are widely used in daily life because of their excellent properties such as strong anti-corrosion ability, low electrical and thermal conductivity, high strength-to-weight ratio, and low cost to manufacture. Studies show that the production and consumption of plastics are up to 300 million tons per year [1], but plastics' recycling is not efficient due to low recovery rates and high cost [2]. Therefore, at least $10 \%$ of plastic waste enters the marine environment, which causes serious plastics pollution especially the microplastics pollution around the world [3]. In addition to the marine environment, microplastics pollution has also been found in continental waters and soil ecosystems [4-8]. Microplastics are generally referred to plastic particles smaller than $5 \mathrm{~mm}$ in size $[9,10]$. They have various colors (blue, red, black, transparent/white, etc.) and can be classified into different shape classes such as fragment, film, fiber, foam, and pellet [11,12]. The origins of microplastics include the primary and secondary sources. Primary microplastics are produced directly from the plastic production process or the pharmaceutical and personal care products (PPCPs) containing microbeads $[5,13]$. The secondary sources of microplastics include fragments or fibers resulting from the breakdown or weathering of plastic debris in natural environments $[14,15]$.

The chemical properties of microplastics are relatively stable, and their degradation processes are extremely slow [16], and thus, microplastics potentially persist for a very long time in the environment [2]. Microplastics have been proved to have negative impacts on the growth of microalgae, shrimp, mussel, fish, and other organisms [10,17-22]. Moreover, the long-term aging and degradation of microplastics will release toxic additives such as antibacterial agents and plasticizers, which can also bring adverse effects to ecosystems [12,23]. 
Previous studies showed that microplastics have been frequently detected in the Pacific Ocean, Atlantic Ocean, and even in the Polar regions [24-28]. However, the investigation on microplastics pollution is still in the early stage so far, and data on their sources and distributions still need further enrichment. Microplastics comprise a very heterogeneous assemblage of pieces, which vary in physical properties and chemical characteristics. Thus, different approaches have been used to identify and quantify microplastics. In order to adequately estimate the composition and abundance of microplastics, it is essential to compare and assess these different approaches to develop standard evaluation methods. Up until now, considerable public attention has focused on the toxic effects of microplastics in the environment. It should be noted that more recent studies have demonstrated the ability of microplastics to carry environmental pollutants. Microplastics, as the potential contaminant vectors, may play an important role in the transport of pollutants from the aquatic environment to the biological chain, which also should be necessarily evaluated.

Therefore, the first main objective of the present work is to summarize and enrich the currently available database on the different methods for the identification and quantification of microplastics, which is expected to promote the establishment of standardized analytical methods. Secondly, the source and distribution of microplastics in the marine environment are reviewed and analyzed. Furthermore, the fate and toxicity effect of microplastics on marine organisms, together with the interaction mechanism between microplastics and environmental pollutants, have been critically evaluated. Lastly, future research directions on microplastics are pointed out. It is believed that understanding the current knowledge surrounding microplastics will provide the theoretical basis for effectively controlling plastics in order to minimize the environmental risks of microplastics.

\section{Identification and Quantification of Microplastics}

In order to assess the distribution and influence of microplastics in natural environments, it is essential to figure out the abundance of microplastics in these environments. However, the nature (such as size, color, surface properties, etc.) of microplastics and also the environment conditions are extremely complex. Therefore, it is important to collect and process the environmental samples through appropriate ways in order to accurately identify and quantify microplastics [29].

The commonly used sampling technologies include selection, volume capacity reduction, and bulk sampling (Figure S1). The steps for sample processing are density separation, filtration, sieving, and visual sorting. Visual sorting is one of the most commonly used methods for the identification of microplastics (using type, shape, and color as criteria). However, this process is very tedious and time consuming, and the rapid methods for sample processing are still lacking $[14,30]$. It also should be noted that there are still no standard procedures for sampling and processing microplastics, and this may prevent the comparison across studies.

Microplastics vary dramatically in size, shape, composition, and other physicalchemical properties; thus, the identification methods mainly focus on the chemical characterization of microplastics to identify their polymer compositions. Up to now, various methods have been applied to characterize microplastics, as shown in Table S1. Fouriertransform infrared spectroscopy (FTIR) and Raman spectroscopy are the two most common analytical methods used to identify microplastics in aquatic samples. FTIR is an appropriate method for the detection of aliphatic compounds and polyesters, and the measurement time is relatively short. However, very small particles $(<10 \mu \mathrm{m})$ are not detectable due to the diffraction limit, and also, the spectra quality depends largely on the sample purity, particle size, and thickness [31]. Raman can identify very small particles (down to $1 \mu \mathrm{m}$ ), and it is very suitable to detect microplastics made of aliphatic, aromatic, or $\mathrm{C}=\mathrm{C}$ compounds. The spectra quality of Raman depends greatly on the measurement parameters and the sample preparation methods. In order to obtain high qualitative Raman spectra, samples should be purified to avoid fluorescence, and the sample-supporting membrane filters should not show any interference to background and Raman signals during the 
spectrum acquisition process [32]. Compared with FTIR, Raman takes much more time for microplastics analysis. The measurement time can be reduced but at the cost of the loss of spectra quality and the decreasing number of detectable particles. Therefore, due to the time-consuming procedures and uncertain extrapolation, the application of FTIR and Raman for reliable monitoring of microplastics is still difficult.

Pyrolysis-gas chromatography in combination with mass spectrometry (Py-GC-MS), a standard method for analyzing polymers, has been frequently used for reliable identification of the isolated microplastics particles by analyzing their thermal degradation products [33]. Py-GC-MS can also be applied for the quantitative trace analysis of microplastics on a polymer specific level based on the highly reproducible pyrolysis conditions [34]. However, it is not suited for analysis of complex environmental sample mixtures because only a single particle can be analyzed in each run [33]. In order to solve this problem, adsorption-desorption as the pretreatment method has been applied to concentrate the thermal degradation products. The sample is subjected to complete thermal decomposition with thermal gravimetric analyzer (TGA) to produce degradation products that will be adsorbed on a solid-phase adsorber [35]. Then, the adsorbed products will be analyzed by thermal desorption gas chromatography mass spectrometry (TDS-GC-MS). Compared with Py-GC-MS, TGA-TDS-GC-MS can analyze a relatively high amount of complex and not homogenous samples, which is 200 times higher than that used in Py-GC-MS. However, for both Py-GC-MS and TGA-TDS-GC-MS, the specific degradation products for the respective polymer have to be selected and analyzed first in order to identify the environmental sample accurately [33-35].

For the quantification of microplastics, the simplest and most commonly used method is counting the numbers through microscopy, which requires separating microplastics first from the obtained samples. However, this manual operation might lead to large systematic errors because of the interference of other non-plastic particles such as sea shells and minerals. Plastics always contain plastic additives such as pigments, stabilizers and plasticizers, flame retardants and so on to improve their mechanical and processing performances. A recent study quantified the microplastics through determining the concentration of additives in microplastics [36]. In that study, the alkali-assisted thermal hydrolysis was first applied to depolymerize polycarbonate (PC) and polyethylene terephthalate (PET) microplastics in a pentanol or butanol system. Then, the concentrations of the depolymerized building block compounds such as bisphenol A and p-phthalic acid were determined with LC-MS /MS to calculate the amount of microplastics. Recoveries could reach $87.2-97.1 \%$ for the PC and PET particles spiked in the landfill sludge. The method was successfully applied to determine the occurrence of PC and PET microplastics in different environmental samples such as marine sediments, indoor dust, salts, and digestive residues in organisms. In addition, this method increased the analyzing efficiency and reduced the loss of microplastics caused by picking, as the separation of microplastics from the samples was unnecessary. However, this method is not suitable to quantify the different microplastics that contain the same building block compound. Thus, the efficiency identification and accurate quantification methods for microplastics analysis still need development and improvement.

\section{Source and Distribution of Microplastics}

\subsection{Source of Microplastics}

The global evaluation of the sources for primary microplastics in marine environment is shown in Figure 1. Synthetic fiber from the textile materials in industrial laundries and households is the largest source of the primary microplastics, accounting for $35 \%$ of the overall sources [37]. These fibers are discharged into sewage water and then potentially end up in the ocean, which can reach up to thousands of particles per cubic meter $[38,39]$. Tire dust from abrasion while driving and city dust from abrasion of infrastructures are another two important sources of the primary microplastics, which account for $28 \%$ and $24 \%$, respectively. In addition, the road markings (such as paint, thermoplastic, preformed polymer tape, and epoxy), marine coatings (such as paint, polyurethane, and epoxy), PPCPs, 
and also plastic pellets all account for a certain proportion for the sources of microplastics. As a result of the potential environmental risks of microplastics, experts are calling for a ban on using microbeads, which is present in PPCPs $[13,40]$. Recently, the effluent of wastewater treatment plants (WWTPs) as the dominant origin of microplastics pollution has attracted extensive concern. All of the above-mentioned primary microplastics may enter into WWTPs, escaping the treatment processes and then being discharged into natural waters. McCormick et al. investigated a highly urbanized river in Chicago, Illinois, USA, and found that concentration of microplastics reached or exceeded the quantities in the Great Lakes and the oceans [5]. The efficiency of WWTPs for microplastics removal can reach as high as $98.41 \%$ [41]. However, because the amount of effluent in WWTPs daily is great and the treatment processes are implemented worldwide, the total amount of microplastics discharged into the environment is still significantly huge [11]. Waste disposal, surface run-off, and atmospheric fallout also contribute to the increase of microplastics.

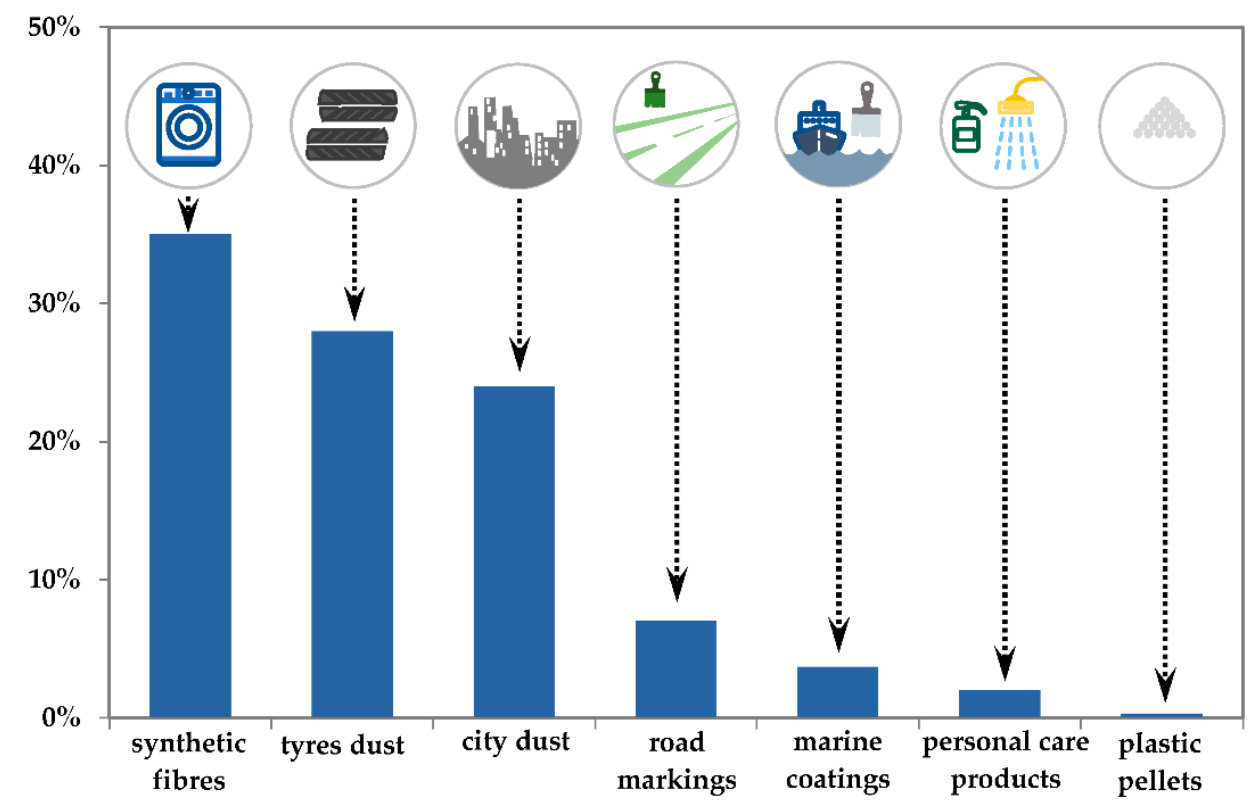

Figure 1. Global evaluation of sources for primary microplastics in the marine environment.

The decomposition of large plastic products is the dominant source of secondary microplastics in the marine environment as $80 \%$ of the marine debris is derived from land [42,43]. Plastics garbage from offshore platforms is also an important contributor. It is reported that lost or discarded fishing and entertaining polymer ropes in sailing boats can be degraded and transfer from the intertidal zone to the marine environment [44]. Plastics, especially those with chromophoric groups, may undergo photochemical reactions caused by the exposure of ultraviolet (UV) radiation. Their surfaces become weak and easy to break up, and then, they generate microplastics via friction by mechanical abrasion such as wind, waves, and sand [45]. Beaches have been considered to be the most favorable places for plastic weathering and fragmentation. Song et al. investigated the formation process of microplastics made of polypropylene (PP) and expanded polystyrene (EPS) with the treatment of 12 months of UV exposure followed by 2 months of mechanical abrasion with sand. They found that PP and EPS could produce as high as $6084 \pm 1061$ and 12,152 \pm 3276 particles/pellet under the simulated beach environment [46]. In addition, plastic floats used in aquaculture facilities and docks can be fragmented because of the boring activity of isopods, and one adult isopod would create 4900-6300 microplastics particles during the boring process [47]. 


\subsection{Distribution and Abundance of Microplastics}

The distribution of microplastics may be affected by the change of global climate including temperature, latitude, UV intensity and so on. All cycle models show that microplastics exist in the ocean circulation, and ocean currents act as the conveyor of collection and accumulation of microplastics. Firstly, the change of the seasonal expansion and shrink of glacier will affect the flow flux of microplastics, because microplastics can be trapped by ice, and when the ice melts, microplastics can be released. Secondly, the density of most microplastics is equal to or less than the density of water, and some stronger evaporation zones will increase the density of water, which result in most of the microplastics floating on the sea and spreading to distant places with the current. The change of climate will lead to global warming; subsequently, the wind is affected, and then the wind will lead to the change of the flow of surface waters, so it is one of the reasons for changing the distribution of microplastics. Moreover, the increase of wind speed will lead to the increase of vertical mixing, which increases the amount of microplastics under a certain depth [48]. Therefore, investigating the distribution of the microplastics is significant to study the source and influence of microplastics [49].

In the recent years, microplastics have been found globally in the oceans and coastal areas, and even the deep sea and the Polar areas are not left out. Table 1 summarizes the distribution and abundance of microplastics in global regions. Levels of 0.116 particles $/ \mathrm{m}^{2}$ and 1.25 particles $/ \mathrm{m}^{2}$ were reported in the north and central-western Mediterranean Sea, respectively $[26,50]$. In the coastal areas of Turkey and France, the average microplastics abundance was calculated to be 0.376 particles $/ \mathrm{m}^{2}$ and 0.24 particles $/ \mathrm{m}^{3}$, respectively [51,52]. The level of microplastics abundance in San Francisco Bay was higher than other urban water bodies in North America with an average abundance of $7.0 \times 10^{5}$ particles $/ \mathrm{km}^{2}$ [53]. Gewert et al. reported the similar abundance of microplastics $\left(4.2 \times 10^{5}\right.$ particles $\left./ \mathrm{km}^{2}\right)$ in Stockholm Archipelago, Baltic Sea [54]. In addition to the surface water, microplastics have been also detected frequently in gyres, estuaries, and sediments. For example, microplastics concentration of 13-501 particles $/ \mathrm{m}^{3}$ was observed in the North Atlantic Subtropical Gyre [25]. In the Lagoon of Venice, Italy, the density of microplastics in sediment reached as high as 2175 particles/kg dry weight [27]. In semi-enclosed bays and nearshore areas of South Korea, microplastics abundance even reached 2000 particles $/ \mathrm{m}^{3}$ [55].

It is known that a high percentage of microplastics pollution starts in inland areas and is then transported via rivers and lakes to marine systems. An average microplastics density of $2.0 \times 10^{4}$ particles $/ \mathrm{km}^{2}$ has been found in Lake Hovsgol, Mongolia [56]. In Lake Winnipeg, Canada, the mean concentration was about $1.93 \times 10^{5}$ particles $/ \mathrm{km}^{2}$ [57]. While in Subalpine Lake Garda, Italy, the mean abundance of microplastics was calculated as 75 particles $/ \mathrm{m}^{2}$ [6]. As mentioned before, WWTPs are the dominant pathway of microplastics from land to natural waters and finally into the oceans. WWTPs can be viewed as a sink for microplastics from terrestrial systems. A significantly higher abundance of microplastics in WWTPs was detected compared to that in freshwaters and the marine environment. Lares et al. reported that the microplastics concentration was $57.6 \times 10^{3}$ particles $/ \mathrm{m}^{3}$ in the influent of Kenkäveronniemi WWTPs located in Finland. Even after high removal treatment with advanced membrane bioreactor technology, the microplastics abundance in effluent was still as high as $1.0 \times 10^{3}$ particles $/ \mathrm{m}^{3}$ [58]. Murphy et al. investigated the removal of microplastics in a secondary WWTP in Glasgow, Scotland, and they estimated that 65 million microplastics would be released into the receiving water every day, even though the concentration of microplastics substantially reduced from $15.7 \times 10^{3}$ particles $/ \mathrm{m}^{3}$ to $0.25 \times 10^{3}$ particles $/ \mathrm{m}^{3}$ [11]. In Australia and Germany, the similar high abundance of microplastics in effluent of WWTPs has also been reported [59,60].

According to Table 1, the common detected types of microplastics include fragments (generated by the breakdown of larger plastic pieces), fibers, films, pellets, and foams, in which fibers and fragments are dominant for most of the research locations. In the Atlantic Ocean, $94 \%$ of microplastics were in the form of fibers [61]. Peng et al. found the similar result that fibers accounted for $93 \%$ of microplastics in sediment of Chang Jiang Estuary, 
China [62]. A relatively high proportion of fibers was also detected in San Francisco Bay, Baltic Sea, and the Belgian coast $[53,54,63]$. In addition, fragments are another predominant composition in microplastics found in most of the current study locations. For example, fragments made up 93.2\% of microplastics in the central-western Mediterranean Sea [50], and over $50 \%$ of fragments microplastics were also detected in the northeast Levantine coast, South Pacific subtropical gyre, Bay of Brest in France [28,51,52]. It can be seen from Table 1 that the most common composition of microplastics is polyethylene (PE) and PP. PE and PP are the two most commonly used plastics in both industrial and household applications such as packing, textiles, cosmetics, and so on. The chemical composition provides some possible information on the source of microplastics. For example, the high proportion of PE and PP microplastics in Stockholm Archipelago matched well with their production amount [54].

As the distribution and abundance of microplastics increases in the marine environment, the presence of microplastics in marine organisms also increases. Microplastics have been detected in various organisms from large mammals to small mollusks (Table 1). For example, Alomar and Deudero investigated the ingestion of microplastics by 125 blackmouth catsharks and found that $16.80 \%$ of the analyzed sharks ingested $0.34 \pm 0.07$ microplastics/individual [64]. Halstead et al. reported the occurrence of microplastics ingestion by benthic-foraging fishes in the Sydney Harbor of Australia, which was in the range of 0.2-4.6 particles/individual for the different species. It seems that microplastics abundance was relatively higher in lower trophic levels organisms, which suggested that microplastics can be transferred along food chains across various trophic levels [65]. Wild mussels Mytilus edulis sampled from the UK coastal waters contained microplastics of 6.4 particles/individual [66], while the number of microplastics collected in one mollusk species from the Persian Gulf of Iran reached as high as 17.7 particles/individual [67]. High microplastics pollution also occurred in cultured organisms for seafood such as oysters and sea cucumbers $[68,69]$. Therefore, certain sensitive organisms such as mussels are proposed as a suitable bio-indicator for microplastics pollution because of their global distribution and susceptibility to microplastics uptake [66]. The most common microplastics presented in marine organisms were fibers and fragments, which were similar to the types of microplastics in marine waters and sediments. However, the microplastics compositions were mainly $\mathrm{CP}, \mathrm{PET}$, acrylic, and rayon, which was different from that in marine environment samples. CP is widely used in food packaging and cigarette wrappers, while PET, acrylic, and rayon are always used in both textile industry and fishing gears. 
Table 1. The distribution and abundance of microplastics in global regions.

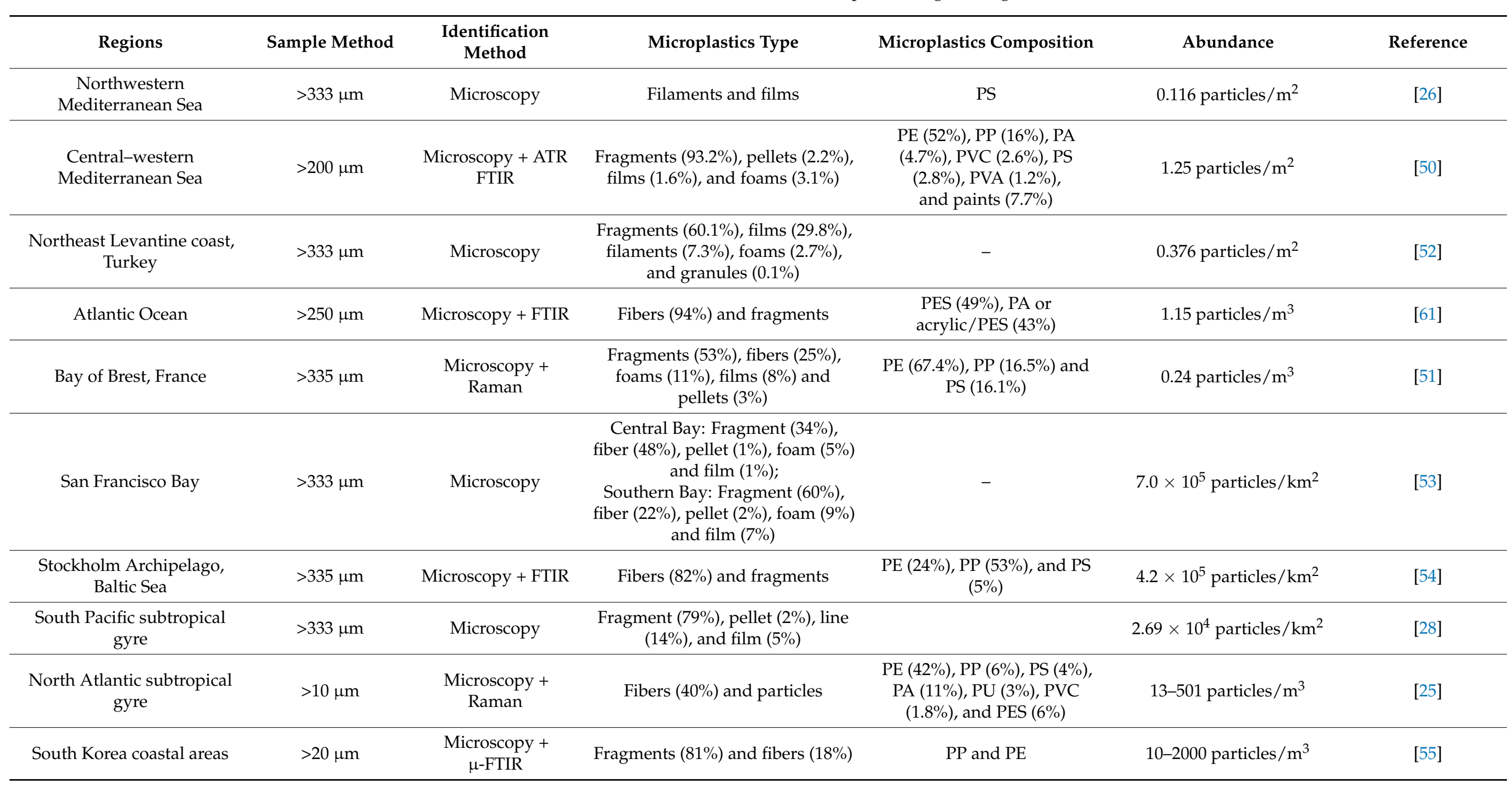


Table 1. Cont

\begin{tabular}{|c|c|c|c|c|c|c|}
\hline Regions & Sample Method & $\begin{array}{l}\text { Identification } \\
\text { Method }\end{array}$ & Microplastics Type & Microplastics Composition & Abundance & Reference \\
\hline Goiana Estuary, Brazil & $>45 \mu \mathrm{m}$ & Microscopy & $\begin{array}{l}\text { Soft plastic }(41.08 \%) \text {, paint chips } \\
(29.11 \%) \text {, hard plastic }(28.42 \%) \\
\text { and threads }(1.4 \%)\end{array}$ & - & 0.26 particles $/ \mathrm{m}^{3}$ & {$[70]$} \\
\hline $\begin{array}{l}\text { Sediment of Chang Jiang } \\
\text { Estuary, China }\end{array}$ & - & $\begin{array}{l}\text { Microscopy }+ \\
\mu \text {-FTIR }\end{array}$ & $\begin{array}{c}\text { Fibers }(93 \%) \text {, fragments }(6 \%), \\
\text { and pellets }(1 \%)\end{array}$ & $\begin{array}{c}\text { Rayon }(63.1 \%), \text { PES }(18.5 \%), \\
\text { and acrylic }(13.9 \%)\end{array}$ & 121 particles $/ \mathrm{kg}$ d.w. & {$[62]$} \\
\hline $\begin{array}{l}\text { Sediment of Lagoon of } \\
\text { Venice, Italy }\end{array}$ & $>32 \mu \mathrm{m}$ & $\begin{array}{c}\mu-F T I R+ \\
\text { ESEM-EDS }\end{array}$ & $\begin{array}{c}\text { Fragments }(86 \%) \text {, fibers }(11 \%) \text {, } \\
\text { films }(2 \%) \text {, and pellets/granules } \\
(1 \%)\end{array}$ & PE, PP, and PS & 672-2175 particles/kg d.w. & {$[27]$} \\
\hline $\begin{array}{l}\text { Sediment of Bay of Brest, } \\
\text { France }\end{array}$ & $>335 \mu \mathrm{m}$ & $\begin{array}{l}\text { Microscopy }+ \\
\text { Raman }\end{array}$ & $\begin{array}{c}\text { Fragments }(71 \%), \text { fibers }(21 \%), \\
\text { and films }(8 \%)\end{array}$ & $\begin{array}{c}\text { PE (53.3\%), PP (30\%), and PS } \\
(16.7 \%)\end{array}$ & 0.97 particles / kg d.w. & {$[51]$} \\
\hline Sediment of Belgian coast & $>38 \mu \mathrm{m}$ & Microscopy + FTIR & $\begin{array}{c}\text { Fibers (59\%), granules ( } 25 \%) \text {, films } \\
(4 \%), \text { and spherules }(12 \%)\end{array}$ & PP, PS, nylon, PVA, and PE & 390 particles $/ \mathrm{kg}$ d.w. & [63] \\
\hline $\begin{array}{l}\text { Sediment of North Atlantic } \\
\text { Ocean }\end{array}$ & $>35 \mu \mathrm{m}$ & $\begin{array}{c}\text { Microscopy }+ \\
\mu \text {-Raman }\end{array}$ & Particles & $\mathrm{PE}$ and PP & 3 particles $/ 25 \mathrm{~cm}^{3}$ & [71] \\
\hline Lake Hovsgol, Mongolia & $>333 \mu \mathrm{m}$ & Microscopy & $\begin{array}{c}\text { Fragment }(40 \%) \text {, foam }(38 \%), \\
\text { line/fiber }(20 \%) \text {, pellet }(1 \%), \\
\text { and film }(1 \%)\end{array}$ & - & $2.0 \times 10^{4}$ particles $/ \mathrm{km}^{2}$ & [56] \\
\hline Lake Winnipeg, Canada & $>333 \mu \mathrm{m}$ & $\begin{array}{l}\text { Microscopy + } \\
\text { SEM-EDS }\end{array}$ & Fibers ( $>90 \%)$, films, and foam & - & $1.93 \times 10^{5}$ particles $/ \mathrm{km}^{2}$ & [57] \\
\hline $\begin{array}{l}\text { Kenkäveronniemi WWTPs, } \\
\text { Finland }\end{array}$ & $>250 \mu \mathrm{m}$ & $\begin{array}{l}\text { Microscopy + FTIR } \\
+ \text { Raman }\end{array}$ & $\begin{array}{c}\text { Fibers }(82.8 \%) \text { and particles } \\
(11.4 \%)\end{array}$ & $\begin{array}{l}\text { PES }(79.1 \%), \text { PE }(11.4 \%) \\
\text { and PA }(3.7 \%)\end{array}$ & $\begin{array}{l}\text { Influent: } 57.6 \times 10^{3} \\
\text { particles } / \mathrm{m}^{3} \\
\text { Effluent: } 1.0 \times 10^{3} \\
\text { particles } / \mathrm{m}^{3}\end{array}$ & [58] \\
\hline WWTPs in Sydney, Australia & $>25 \mu \mathrm{m}$ & $\begin{array}{l}\text { Microscopy + } \\
\text { ATR-FTIR }\end{array}$ & PE, PET, Nylon, PP, PS, PVC & - & $\begin{array}{l}\text { Effluent: } 1.5 \times 10^{3} \\
\text { particles } / \mathrm{m}^{3}\end{array}$ & {$[60]$} \\
\hline $\begin{array}{l}\text { WWTPs in Glasgow, } \\
\text { Scotland }\end{array}$ & $>65 \mu \mathrm{m}$ & Microscopy + FTIR & $\begin{array}{c}\text { Flakes }(67.3 \%) \text {, fibers }(18.5 \%) \text {, film } \\
(9.9 \%) \text {, beads }(3.0 \%) \text {, and foam } \\
(1.3 \%)\end{array}$ & $\begin{array}{l}\text { PES }(28 \%), \text { PA }(20 \%), \text { PP } \\
(12 \%) \text {, acrylic }(12 \%), \text { alkyd } \\
(8 \%), \text { PE }(4 \%), \text { PS }(4 \%), \\
\text { and PET }(4 \%)\end{array}$ & $\begin{array}{l}\text { Influent: } 15.7 \times 10^{3} \\
\text { particles } / \mathrm{m}^{3} \\
\text { Effluent: } 0.25 \times 10^{3} \\
\text { particles } / \mathrm{m}^{3}\end{array}$ & [11] \\
\hline
\end{tabular}


Table 1. Cont

\begin{tabular}{|c|c|c|c|c|c|c|}
\hline Regions & Sample Method & $\begin{array}{l}\text { Identification } \\
\text { Method }\end{array}$ & Microplastics Type & Microplastics Composition & Abundance & Reference \\
\hline $\begin{array}{l}\text { WWTPs in Lower Saxony, } \\
\text { German }\end{array}$ & $>10 \mu \mathrm{m}$ & Microscopy + FTIR & - & $\mathrm{PP}, \mathrm{PE}$, and $\mathrm{PA}$ & $\begin{array}{c}\text { Effluent: } 9 \times 10^{3} \\
\text { particles } / \mathrm{m}^{3}\end{array}$ & [59] \\
\hline $\begin{array}{c}\text { Shark Galeus melastomus } \\
\text { from western Mediterranean } \\
\text { Sea }\end{array}$ & Filed study & Microscopy + FTIR & $\begin{array}{l}\text { Filaments }(86.36 \%) \text {, fragments } \\
(12.12 \%) \text {, and film }(1.51 \%)\end{array}$ & $\begin{array}{c}\text { CP }(33.33 \%), \text { PET }(27.27 \%), \\
\text { PP }(12.12 \%), \\
\text { and polyacrylate }(12.12 \%)\end{array}$ & $\begin{array}{c}0.34 \pm 0.07 \\
\text { particles/individual }\end{array}$ & {$[64]$} \\
\hline $\begin{array}{c}\text { Fishes in Sydney Harbour, } \\
\text { Australia }\end{array}$ & Filed study & $\begin{array}{l}\text { Microscopy + } \\
\text { ATR-FTIR }\end{array}$ & Fibers $(83 \%)$ and granules $(17 \%)$ & acrylic, PES, and rayon & 0.2-4.6 particles/individual & [65] \\
\hline $\begin{array}{l}\text { Hymenaster pellucidus from } \\
\text { North Atlantic Ocean }\end{array}$ & Filed study & $\begin{array}{l}\text { Microscopy + } \\
\text { ATR-FTIR }\end{array}$ & Fibers $(87 \%)$ and fragments (13\%) & acrylic & $\begin{array}{c}1.62 \pm 0.9 \text { particles /gram } \\
\text { tissue }\end{array}$ & [72] \\
\hline $\begin{array}{l}\text { Shrimp Aristeus antennatus } \\
\text { from northwestern } \\
\text { Mediterranean Sea }\end{array}$ & Filed study & Microscopy + FTIR & Fibers & $\begin{array}{l}\text { PET }(57.1 \%), \text { PA }(28.6 \%) \\
\text { and rayon }(14.3 \%)\end{array}$ & - & [73] \\
\hline $\begin{array}{l}\text { Molluscs from the Persian } \\
\text { Gulf, Iran }\end{array}$ & Filed study & Microscopy + FTIR & $\begin{array}{c}\text { Microfibers }(>50 \%) \text {, fragments } \\
(26 \%) \text {, films }(14 \%) \text {, and pellets } \\
(2 \%)\end{array}$ & PE, PET, and nylon & 3.7-17.7 particles/individual & {$[67]$} \\
\hline Cultured oysters from China & Filed study & $\begin{array}{l}\text { Microscopy + } \\
\mu \text {-FTIR }\end{array}$ & $\begin{array}{c}\text { Fibers }(60.67 \%) \text {, fragments } \\
(19.95 \%), \text { films }(10.26 \%), \\
\text { and pellets }(9.11 \%)\end{array}$ & $\begin{array}{c}\text { CP }(41.34 \%), \text { PE }(22.97 \%), \\
\text { PET }(15.19 \%), \text { PP }(9.89 \%), \text { PA } \\
(4.95 \%), \text { PS }(2.47 \%), \text { PC } \\
(1.77 \%), \text { and PVC }(1.41 \%)\end{array}$ & 2.93 particles/individual & [69] \\
\hline $\begin{array}{l}\text { Cultured sea cucumbers } \\
\text { from China }\end{array}$ & Filed study & $\begin{array}{c}\text { Microscopy }+ \\
\mu \text {-FTIR }\end{array}$ & Fibers, fragments, and pellets & $\mathrm{CP}$ & 10 particles/individual & {$[68]$} \\
\hline
\end{tabular}

PE: polyethylene, PA: polyamides, PVC: polyvinyl chloride, PS: polystyrene, PET: polyethylene terephthalate, PVA: polyvinyl alcohol, PES: polyester, CP: cellophane. 


\section{Fate and Effects of Microplastics in the Marine Environment}

\subsection{Effects of Microplastics on Marine Organisms}

According to the current field surveys, microplastics have been widely detected in various natural marine organisms. Ingestion has been widely accepted as the primary way for the marine organisms to uptake microplastics because the particles are always mistaken for food. About 15.06 particles/organism of microplastics was observed in Daphnia magna when exposed to $100 \mathrm{mg} / \mathrm{L}$ of PE microbeads for 21 days [74]. The ingestion of microplastics varies with the particle size, surface properties, and the age of marine organisms. Cole and Galloway found that the proportion of oysters ingesting microplastics decreased with increasing plastic size. Older oyster larvae could consume a full range of microplastics, and positive-charged microplastics were accumulated more than the virgin and negative-charged microplastics [75]. Although relative high ingestion by marine organisms, no significant negative effects were found on their normal growth, survival, and reproduction [3,76-78]. Ingested microplastics particles could be readily well egested and depurated from organisms, thus resulting in no acute biological effects $[75,78]$.

However, more and more studies reported the negative effects of microplastics on some sensitive organisms. Prolonged exposure to PS microplastics significantly altered the feeding capacity and physically inhibited the fertilization of marine copepods, resulting in the decrease of reproductive output $[79,80]$. Gardon et al. investigated the impact of PS microbeads on the physiology of oysters and found a significant decrease of assimilation efficiency because of the decrease in energy gain. Oysters' gonads might provide the missing energy to maintain their metabolism from the energy balance perspective, thus producing the negative repercussions on reproduction [81]. Microplastics could also cause significant effects on marine organisms at the tissue and cellular levels. von Moos et al. reported that Mytilus edulis L. presented strong inflammatory response when exposed to PE microplastics. PE particles would be taken into the stomach, transported into the digestive gland, and accumulated in the lysosomal system of the mussel, which brought the formation of granulocytomas and lysosomal membrane destabilization [82]. PS microplastics were also accumulated in the zebrafish organs and then caused the inflammation and lipid accumulation in fish liver [83]. Recently, several studies have attempted to reveal the toxicity effect of microplastics at the molecular and even genetic levels. Microplastics could lead to significant adverse effects on the growth and reproduction of monogonont rotifer, with the increasing of the reactive oxygen species (ROS) production and the enzymatic activities of antioxidants. The mitogen-activated protein kinases (MAPKs) signaling pathways were significantly activated to defend against the microplastics-induced oxidative stress [84]. Similarly, a significant increase in the activities of antioxidant enzymes and decrease in the detoxifying enzymes were also observed for coral reef to acute microplastics exposure. Transcriptomic analysis revealed that 134 and 215 coral genes related with c-Jun $\mathrm{N}$-terminal kinase (JNK) and extracellular regulated protein kinase (ERK) signal pathways were up-regulated and down-regulated, respectively, to repress the detoxification and immune system [85].

There are various factors influencing the toxicity of microplastics. Size-dependent negative effects of microplastics have been reported frequently. Lu et al. found that $5 \mu \mathrm{m}$ PS accumulated in zebrafish gills, liver, and gut, while $20 \mu \mathrm{m}$ PS only accumulated in gills and gut because the $5 \mu \mathrm{m}$ particles could enter the circulatory system and be transferred to the liver [83]. Lee et al. investigated the two-generation chronic toxicity of different-sized PS microbeads on copepod Tigriopus japonicus. The results showed that the copepod mortality reached over $10 \%$ when exposed to $0.05 \mu \mathrm{m}$ PS microbeads at $1.25 \mu \mathrm{g} / \mathrm{mL}$. For $0.5 \mu \mathrm{m}$ PS microbeads, only the highest concentration $(25 \mu \mathrm{g} / \mathrm{mL})$ significantly decreased the survival of the F1 generation. The $6 \mu \mathrm{m}$ PS microbeads did not affect the survival of both F0 and F1 generations [80]. Similar size-dependent effects of PS microbeads on monogonont rotifer have also been observed. Jeong et al. found that $0.05 \mu \mathrm{m}$ microbeads exerted the most deleterious effects on the growth rate, fecundity, life span, and reproduction time of Brachionus koreanus. The antioxidant-related enzymes and MAPK signaling pathways 
were significantly activated in a size-dependent manner [84]. All the results revealed that smaller microplastics were more toxic, which indicated that the environmental effects of nano-sized plastics needed more research attention.

The toxicity of microplastics also depends on their surface chemistry. In laboratory studies, functionalized microbeads are always used to investigate the impact of surface properties on microplastics toxicity. Watt et al. found no significant adverse impact of both carboxylated PS (PS-COOH) and aminated PS (PS- $\mathrm{NH}_{2}$ ) on gill function of shore crab Carcinus maenas, but their distributions in gills were quite different because of their different surface-binding capacity within the gill tissues [86]. Della Torre et al. observed that PS-COOH had no toxicity and only accumulated in the digestive tracts of sea urchin embryos, while $\mathrm{PS}-\mathrm{NH}_{2}$ had severe developmental defects on embryos as they caused cellular apoptosis and embryonic malformations [87]. A similar higher toxicity of $\mathrm{PS}^{-\mathrm{NH}_{2}}$ on Pacific oyster larvae has been observed because PS- $\mathrm{NH}_{2}$ beads were consumed and retained in the intestinal tract for longer than PS and PS-COOH beads [75]. Luan et al. also found that $\mathrm{PS}^{-\mathrm{NH}_{2}}$ was more toxic than PS-COOH to clams at three key development stages of their life history, as the smaller particle size and positive surface charges of $\mathrm{PS}_{-} \mathrm{NH}_{2}$ favored the damage of embryo membrane and the translocation through the digestive gland [88]. What is more, functional groups could enhance the combination toxicity of microplastics with other chemicals. Kim et al. found that the immobilization of Daphnia magna exposed to Ni combined with PS-COOH was higher than that of Daphnia magna exposed to Ni combined with PS [89].

In addition to the adverse physiological effects aroused from the direct contact or ingestion of the microplastics to marine organisms, microplastics, especially those containing additives, may also pose additional hazardous effects. Most additives are not chemically but physically bound to the plastic; therefore, the leaching of these additives from microplastics could be accelerated through the breakdown or swelling in natural marine environment and became available to marine organisms [90]. To investigate the potential risk, $\mathrm{Li}$ et al. quantified the effects of leachates from seven recyclable plastics on the survival and settlement of barnacle Amphibalanus amphitrite. The results revealed that leachates from plastics significantly increased the barnacle nauplii mortality and inhibited barnacle cyprids settlement on glass. A high number of chromatographic features were detected, revealing that a complex mixture of substances was released in plastic leachates, which were associated with resultant toxicity [91]. Similarly, Oliviero et al. exposed the sea urchin Paracentrotus lividus to the micro-sized PVC commercial products and found that the leached substances resulted in the decrease of larval length in plutei and the block of larval development in sea urchin embryos [92]. In addition to the man-made microplastics, several studies investigated the leachate toxicity associated with the natural collected microplastics. Nobre et al. studied the effects of virgin and beach-collected microplastics on the development of Lytechinus variegatus embryos. The results showed that the toxicity of virgin microplastics was higher than that of the beach-collected microplastics with increasing anomalous embryonic development up to $66.5 \%$, which was attributed to the higher amount of plastics additives in virgin plastic particles [93]. However, a higher toxicity of natural collected microplastics has been also observed compared with that of the virgin microplastics. Gandara e Silva et al. found that the embryo development of brown mussels was very sensitive to the leachate from microplastics, and the beached microplastics caused 100\% dead and abnormal embryos compared with $23.5 \%$ from the virgin microplastics. The authors suggested that the contaminants desorbed from the surface of beached microplastics were much more toxic than the additives leached from the virgin microplastics [94]. A recent study compared the in vitro and in vivo toxicity of leachates from North Pacific gyre plastics together with UV-treated and untreated plastics. Similarly, the North Pacific Gyre-recovered plastic leached the highest chemical estradiol equivalent and toxic equivalency compared with the untreated and UV-irradiated plastics, which significantly induced cyp1a mRNA in Oryzias latipes larvae. The results demonstrated that the weathering and desorption of adsorbed PCBs, PAHs, and other estrogenic plasticizers were responsible for the high toxic effects of natural collected microplastics [95]. Thus, 
studies are still needed to explore the interaction between different kinds of contaminants with microplastics and their resulting toxicity to organisms under environmental-relevant conditions.

\subsection{Toxic Effects of Microplastics on Marine Microalgae}

At present, studies on the toxic effects of microplastics on marine organisms mainly focus on animals but rarely on phytoplankton, especially microalgae. Microalgae are the primary producers in the marine ecosystem and play an important role in maintaining the long-term stability of the marine environment. The obvious toxic effect of microplastics on algae is growth inhibition [96-98]. Exposed to PVC microplastics $(1 \mu \mathrm{m})$, the growth of Skeletonema costatum was reported to reduce by $39.7 \%$ at $96 \mathrm{~h}$ under $50 \mathrm{mg} / \mathrm{L}$ treatment [99], and the inhibitory rate for Karenia mikimotoi was $45.8 \%$ at $24 \mathrm{~h}$ under $100 \mathrm{mg} / \mathrm{L}$ treatment [100]. The growth inhibition effect also increased with the decreasing of particle size [101,102]. The inhibition effect of $6 \mu \mathrm{m}$ PS particles on the growth of Dunaliella tertiolecta was not significant, but it increased by $13 \%$ and $57 \%$ in the presence of $0.5 \mu \mathrm{m}$ and $0.05 \mu \mathrm{m}$ PS particles, respectively [103]. Along with the inhibition effects of microplastics on microalgae, the metabolic responses of algal cells were also affected obviously [96,104-106]. After $48 \mathrm{~h}$ exposure of $\mathrm{PS}-\mathrm{NH}_{2}$, the reduction of chlorophyll content and photosynthetic efficiency of the diatom Chaetoceros neogracile reached $24 \%$ and $13 \%$, moreover, a significant increase of intracellular ROS was also detected [104], which might cause the lipid peroxidation. Our previous study revealed that the contents of malondialdehyde (MDA), one main lipid peroxidation product, increased even more than ten times in the presence of microplastics compared with the control [107].

Although the above toxic effects of microplastics on microalgae have received more attention, the toxicity mechanism is quite complex (Figure 2). First, as microplastics have various shapes and rough edges, it is easy to cause mechanical damage to algae cells, such as the cell wall damage and cell fragmentation [107-110], which may eventually lead to algal cells death. The mechanical damage becomes more serious with the increasing of the microplastics concentration. Zhang et al. reported that PVC could be adsorbed on the surface of algal cells and embedded into the cell wall, resulting in damage to the cell walls and membranes [99]. The mechanical damage to algal cells has also been confirmed for the other nanoparticles such as $\mathrm{Nano}_{-} \mathrm{TiO}_{2}, \mathrm{ZnO}$, and carbon nanotubes [111-113], but there is no clear evidence to prove that microplastics can enter living algal cells. However, with the environmental occurrence of nano-sized microplastics [114-117], more research is needed to verify whether microplastics can enter microalgae cells and cause intracellular mechanical damage.

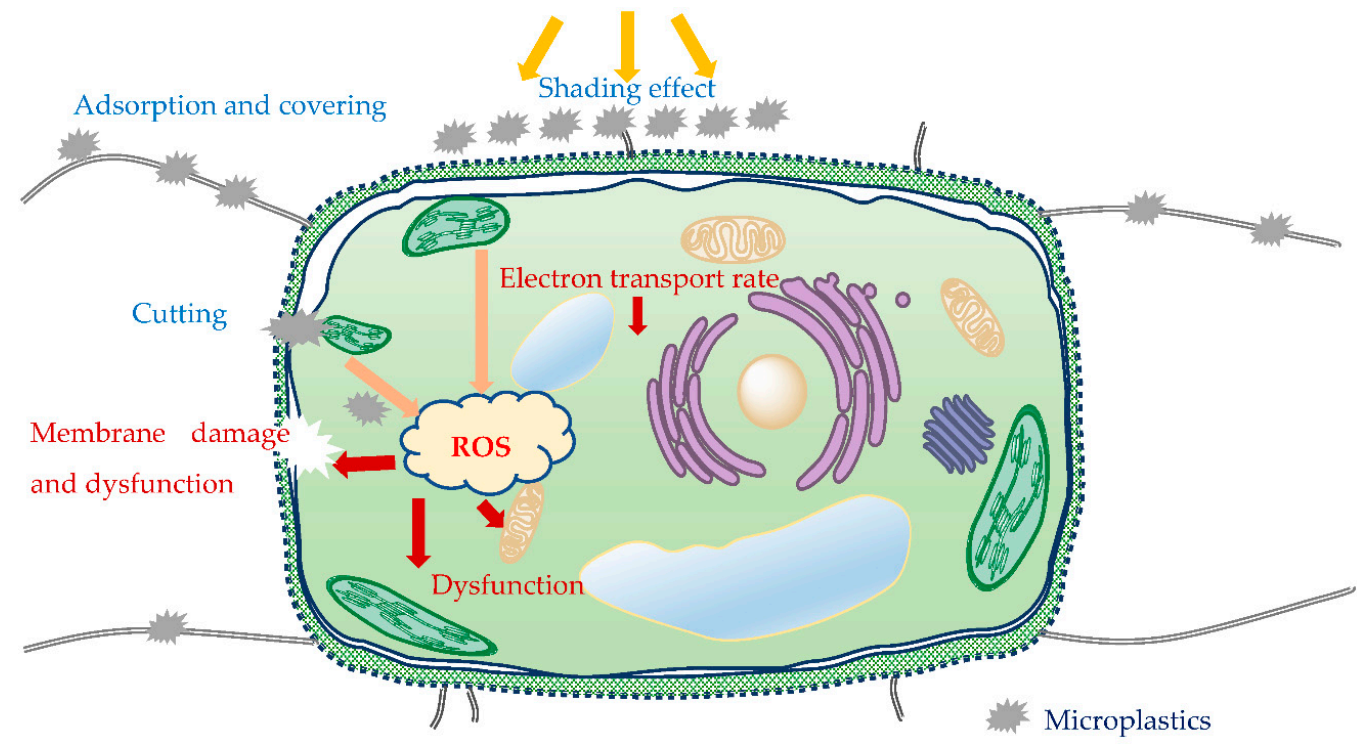

Figure 2. Schematic description of the toxicity mechanisms of microplastics to algae cell. 
Apart from the mechanical damage, microplastics are expected to reduce the photosynthetic efficiency of algae through a shading effect, which is similar to other particles $[97,118-120]$. However, the non-contact shading experiments revealed that microplastics had no significant shading effect on the photosynthesis of microalgae $[99,103]$. The possible reason was that although microplastics could block some light, the rest could still meet the photosynthetic needs of algal cells as the concentration of microplastics was not high enough. However, when microplastics and algal cells contacted with each other, adsorption and hetero-aggregation may become the main reason of toxicity. First, the algal cell surface is rough with flagella, which can provide combining sites for microplastics to adhere on the algae surface [97,121-124]. The formed aggregation can not only affect the movement of microalgae but also block the absorption of light and substance exchange $[97,100,125,126]$. Bhattacharya et al. observed a significant decrease in $\mathrm{CO}_{2}$ depletion in Chlorella because of the severe adsorption of PS on Chlorella cells, and harmful metabolites inside the cells could not be excreted in time, either [125]. Second, the adsorption interaction can also induce other negative effects on the structure of algal cells. For example, after $96 \mathrm{~h}$ exposure to $5 \mathrm{mg} / \mathrm{L}$ of $0.55 \mu \mathrm{m}$ PS, plasmolysis, vacuolation, and distortion of the membrane structures in the Chlorella pyrenoidosa cells were clearly observed through TEM [108]. Furthermore, the aggregation of algal cells and microplastics may become more serious with the increasing of the exposure time, which leads to the complete covering and wrapping of algal cells and death eventually $[111,112]$.

Otherwise, microplastics can also cause oxidative stress in algal cells, resulting in an increase of intracellular ROS content $[96,105,125,127]$. In plant cells, ROS mainly come from the electron transport chain in chloroplasts. When the photosynthetic efficiency decreases, the electron transport efficiency reduces, and then electrons are transferred to $\mathrm{O}_{2}$ instead of $\mathrm{CO}_{2}$ to form the ROS. The increase of ROS causes a lipid peroxidation reaction, which can lead to subcellular structure and cellular function damage, such as weakening the membrane selective transmission function $[128,129]$. It was reported that PS microplastics could induce the reduction of the photosynthetic efficiency and increase the ROS content in Chlorella and Scenedesmus cells [125]. In addition, the smaller the particle size, the stronger the oxidative stress reaction was in algal cells, thus inducing more severe lipid peroxidation in cell membrane $[101,130,131]$. Meanwhile, the activity of antioxidant enzymes such as superoxide dismutase (SOD) and catalase (CAT) will be enhanced to remove ROS, but algal cells will die if the ROS content exceeds their self-repair ability $[96,105,128]$.

Moreover, as we pointed out previously, plastics additives such as plasticizers, antioxidant, flame retardants, and colorants could be leaked in the environment, which affected the toxicity of microplastics to microalgae [90,132-134]. Luo et al. found that the release amount of additives reached a maximum in $24 \mathrm{~h}$, but only the high content microplastics $(>1.6 \mathrm{~g} / \mathrm{L})$ had a significant inhibitory effect on the algal cell photosynthesis [134]. Normally, the additives in plastics are relatively environmentally friendly, but it has to be noted that microplastics can absorb other more toxic pollutants in the environment $[97,135-140]$. These chemicals can be desorbed at certain conditions, which may pose higher toxic risks to microalgae $[141,142]$, which needs more investigation.

\subsection{Trophic Transfer of Microplastics in Marine Food Webs}

As a global pollution, the bioaccumulation and biomagnification of microplastics have attracted more concerns due to their potential risks and toxic effects on top predators. Thus, the trophic transfer of microplastics in marine food webs has been investigated from both field and laboratory studies. Fluorescent PS microspheres $(0.5 \mu \mathrm{m})$ were fed through the food chain from mussels (Mytilus edulis) to crabs (Carcinus maenas), with significant detection of microspheres in the hepatopancreas of the crabs $\left(15,033 \mathrm{~mL}^{-1}\right.$ \pm SE 3146 at 24 h) [143]. Setälä et al. found that $43 \%$ of the copepods and $86 \%$ of the polychaete larvae (Marenzelleria spp.) contained microspheres after $12 \mathrm{~h}$ exposure to PS microspheres $(10 \mu \mathrm{m})$, and obvious transfer of the microspheres to higher trophic level mysid shrimps was observed after $3 \mathrm{~h}$ incubation with the above two mentioned zoo- 
plankton species [144]. Trophic transfer of plastic fragments was also confirmed from the flying fish (Cheilopogon rapanouiensis) to their predator yellowfin tunas (Thunnus albacares) around Rapa Nui in the South Pacific subtropical gyre, even though the microplastics accumulation occurred in only a few (2\%) of the tunas [145]. Microplastics transfer in marine high trophic-level taxa was also observed by in natura study from the prey wildcaught Atlantic mackerel (Scomber scombrus) to marine mammal top predator grey seals seals (Halichoerus grypus) [146]. Up to now, few studies involved the microplastics transfer among more than two trophic levels. Cedervall et al. studied the transport of PS nanoplastics $(24 \mathrm{~nm})$ through a three-level freshwater food chain from algae (Scenedesmus sp.) through zooplankton (Daphnia magna) and then to fish (Carassius carassius), which restrained the normal metabolization of fat reserves and severely disturbed the feeding behavior of the fish [147]. The transfer of PS nanoplastics was recently further investigated among four trophic species, including the algae (Chlamydomonas reinhardtii), water flea (Daphnia magna), secondary-consumer fish (Oryzias sinensis), and end-consumer fish (Zacco temminckii). The authors found that nanoplastics not only caused negative effects on the fish activity and induced the histopathological changes in livers but also threatened the next generation, as the plastics particles could penetrate the embryo walls [148].

After ingestion, most of the microplastics can be egested from organisms, which relieve the negative effects by microplastics in isolation $[75,78]$. However, the ingested microplastics can release additives and the adsorbed pollutants inside the organisms $[95,149,150]$, which may accumulate and transfer more than the microplastics through the food web. Batel et al. investigated the transfer of microplastics and the benzo[a]pyrene through a simple artificial food chain from Artemia sp. Nauplii to zebrafish (Danio rerio) [151]. Microplastics were accumulated and transferred to fish; at the same time, benzo[a]pyrene desorbed from microplastics beads was also detected within intestinal tracts of zebrafish through direct fluorescence tracking. Diepens and Koelmans further established a generic theoretical model to simulate the transfer of microplastics and hydrophobic organic chemicals (HOCs) in food webs comprised of nine species including Atlantic cod and polar bear as the top predator [152]. The results showed that the trophic transfer of HOCs had profound effects on their biomagnification through the food chain. An interesting observation was that PCBs biomagnified less while PAHs biomagnified more when more microplastics were ingested, which was related with the metabolizable property of HOCs [152].

On the other hand, some experimental and theoretical studies predicted that ingested microplastics contaminated by pollutants would not favor chemical transfer to the organisms [153-155]. Grigorakis et al. studied the diet assimilation efficiencies (AEs) of PCBs absorbed to microplastics and food in goldfish (Carassius auratus) [153]. PCBs in microplastics had much lower AEs (13.36\%) than that in food matrix $(51.64 \%)$, and the low bioavailability of microplastics-associated PCBs suggested that microplastics were unlikely to increase HOCs biomagnification by fish in aquatic food webs. Koelmans et al. critically evaluated the possibility of the transfer of HOCs by microplastics [155]. They believed that the fraction of HOCs adsorbed by microplastics was very small compared to that adsorbed by the other marine media; therefore, microplastics ingestion was not likely to increase the exposure and risks of HOCs in the marine environment. At this time, the data on the possible transfer of contaminated microplastics through trophic levels are still lacking. More studies are needed to fulfill this gap in order to provide more evidence on the ecological risk assessment of marine microplastics.

\subsection{Joint Toxicity of Microplastics with Other Chemicals}

Microplastics can interact with environmental pollutants due to their large and relative hydrophobic surface, which may affect the joint toxicity of microplastics and the other chemicals from the individual level to molecular or even genetic levels. Organic contaminants such as PAHs, PCBs, and PBDEs on microplastics could be transferred into organisms [152,156], which led to the accumulation of these chemicals and much higher potential risks to marine organisms. Microplastics increased pharmaceuticals' toxicity to 
marine microalgae (Tetraselmis chuii) with a higher inhibition of growth rate and lower chlorophyll concentration, and EC50 of doxycycline decreased almost 50\% [106]. In the presence of PE microspheres (1-5 $\mu \mathrm{m})$, the pyrene-induced fish mortality, the isocitrate dehydrogenase (IDH) activity, and acetylcholinesterase (AChE) activity were all decreased, which might increase the mortality in natural fish populations [157]. When exposed to a mixture of PE microplastics with PBDEs adsorbed from the marine environment, PBDEs concentration in Oryzias latipes increased significantly. Severe liver histopathology including glycogen depletion, fatty vacuolation, cellular necrosis, and lesions was also observed [158]. Exposure to microplastics and associated chemicals promoted endocrinedisrupting effects in fish, and a significant down-regulation of choriogenin, vitellogen, and estrogen receptor genes' expressions was observed [159]. The severe joint toxicity of microplastics with heavy metal contaminants has also been reported. For example, Luís et al. found that the microplastics-Cr(VI) complex greatly decreased the fish predatory behavior and inhibited the activity of $\mathrm{AChE}(31 \%)$ compared to the individual microplastics and $\mathrm{Cr}(\mathrm{VI})[160]$.

However, up to now, it is still a matter of debate whether their joint toxicity will be enhanced to organisms because the hypothetical roles of microplastics as vectors of environmental contaminants have been challenged. Herzke et al. found that persistent organic pollutants (POPs) concentrations in fulmars from Norway were not in accordance with their stomach plastic concentrations, indicating that plastic did not act as the POPs carrier to fulmars. Through calculation from a dynamic bioaccumulation model, the flux of POPs by the ingestion of natural prey was four orders of magnitude higher than the flux of POPs through plastic ingestion [154]. Even considering different conditions of $\mathrm{pH}$, temperature, and gut surfactants, the predicted contribution of plastics ingestion to the overall body burdens of adsorbed organic contaminants in marine organisms was very small [161]. Both of the above modeling studies suggested that plastics ingestion was not the main way for chemicals bioaccumulation. In laboratory studies, microplastics also failed to enhance organic contaminants toxicity to organisms even under the extreme scenario conditions (microplastics concentration up to ppm level). The addition of microplastics $(10 \mathrm{mg} / \mathrm{L})$ did not increase the toxicity of 4-n-nonlphenol to both normal and starved sea-urchin larvae because sea-urchin larvae could egest microplastics after hours of ingestion without allowing significant pollutants desorption [162]. Even after ingesting relatively high doses of environmental contaminated microplastics, the rainbow trout did not show any obvious adverse hepatic stress in liver, and the fillets quality was not affected, either [163]. However, the specific properties of microplastics should be considered. For example, Kim et al. found that the joint toxicity of origin PS microplastics and Ni to Daphnia magna was antagonistic but synergistic for carboxyl-PS microplastics in combination with Ni [89]. Moreover, nanoplastics $(50 \mathrm{~nm})$ and phenanthrene had additive joint toxicity to Daphnia magna, while microplastics $(10 \mu \mathrm{m})$ did not affect the bioaccumulation, dissipation, and transformation of phenanthrene [164]. These results revealed the important roles of functional groups and particle size of microplastics on their joint toxicity effect. Therefore, further studies on joint toxicity using various microplastics and contaminants are still warranted.

\subsection{The Interactions between Microplastics and Contaminants}

No matter whether microplastics are able to serve as an important transport vector of chemicals, there is no doubt that microplastics can act as the sinks for various contaminants in the environment, which has been found frequently from survey studies on environmental-collected microplastics. Microplastics are capable of concentrating pollutants, increasing their concentrations up to several orders of magnitude greater than those in the background. For example, high levels of PAHs, PCBs, and DDTs were detected in microplastics pellets collected from the Portuguese coast beaches, with the concentrations reaching $44,800 \mathrm{ng} / \mathrm{g}, 223 \mathrm{ng} / \mathrm{g}$, and $41 \mathrm{ng} / \mathrm{g}$, respectively [165,166]. Microplastics in the Canary Islands were reported to carry very high levels of organochlorine pesticides (up to $13,489 \mathrm{ng} / \mathrm{g}$ ), as this region was once most heavily polluted by these pesticides [167]. 
In addition to the organic contaminants, microplastics have also been found contaminated by heavy metals. The presence of $\mathrm{Cd}, \mathrm{Cr}, \mathrm{Cu}, \mathrm{Fe}, \mathrm{Mn}, \mathrm{Ni}, \mathrm{Pb}, \mathrm{Zn}, \mathrm{Al}, \mathrm{Sn}, \mathrm{Ti}$, and $\mathrm{As}$ in beachcollected microplastics have been recently reported [168-171]. The spatial pattern of pollutants in microplastics reflected the differences of these chemicals' application in different coastal regions. Furthermore, the contaminants adsorbed by microplastics still pose the potential to enter into the marine biota, although there are inverse viewpoints $[106,152,156-159]$. Therefore, the interactions between contaminants and microplastics are increasingly being studied to better understand the associated environmental risks.

Different types of microplastics have different affinity to environmental contaminants, which is related with the inherent properties of microplastics (Figure 3). Polymers commonly consist of crystalline regions and amorphous regions, and the crystallinity refers to the proportion of the crystalline regions. Polymer chains are closely packed in the crystalline area but loosely arranged in the amorphous area. In general, polymers with relatively lower crystallinity allow a greater diffusion of contaminants into the polymer than those with higher crystallinity. The adsorption of HOCs such as phenanthrene, lindane, and naphthalene by different types of PE were reported to be negatively correlated with the crystallinity of the polymers [172]; however, crystallinity is not the only influencing factor among the various kinds of microplastics. The adsorption of PAHs, antibiotics, phthalate esters, and perfluoroalkyl substances by the three most common PE, PS, and PVC microplastics showed very different trends, even though their crystallinity followed the order of PE > PS > PVC [139,173-177]. Plastics can be divided into the rubbery-like and glassier-like polymers according to their glass transition temperatures (Tg). PE has a flexible rubbery structure with greater segmental mobility and free volume at room temperature due to relatively low $\mathrm{Tg}$ of about $-120^{\circ} \mathrm{C}$, which favors the diffusion and partition of pollutants into the polymer [178]. PS and PVC can be viewed as glassier polymers with high $\mathrm{Tg}$ values of about $100{ }^{\circ} \mathrm{C}$ and $85^{\circ} \mathrm{C}$, respectively. The presence of the benzene ring and chloride atom reduces the segmental mobility and free volume within the polymers [178]. Thus, PE commonly has a higher affinity for contaminants than the other types of plastics [174-176]. However, this generalization does not always apply to all contaminants. For example, PS was reported to have higher adsorption capacity for tylosin, tetracycline, PCBs, and other organic compounds than PE. The possible reasons were proposed to be the additional $\pi-\pi$ interaction and polar interaction because of the benzene rings $[140,177,179,180]$. Thus, properties of specific microplastics and contaminants should be considered when evaluating their interactions.

There are many other different factors that may affect the adsorption behavior of microplastics. Particle size has been investigated frequently. There is no doubt that the adsorption capacity will increase with the decreasing size of microplastics [181-185]. It should be noted here that nanoplastics are receiving more concerns. Up to now, information on the environmental loads of nanoplastics is still not available. Release from products and the degradation/fragment of larger plastics should be the two most important sources of nanoplastics [186]. During the limited studies on the potential environmental impacts of nanoplastics, nano-PS had almost two orders higher adsorption capacity to PCBs than micro-PE [180]. Nano-PS was also reported to enhance the transport and spread of organic contaminants as an important carrier [187]. Therefore, there is a need for more research to further understand the interactions between nanoplastics and environmental contaminants. 


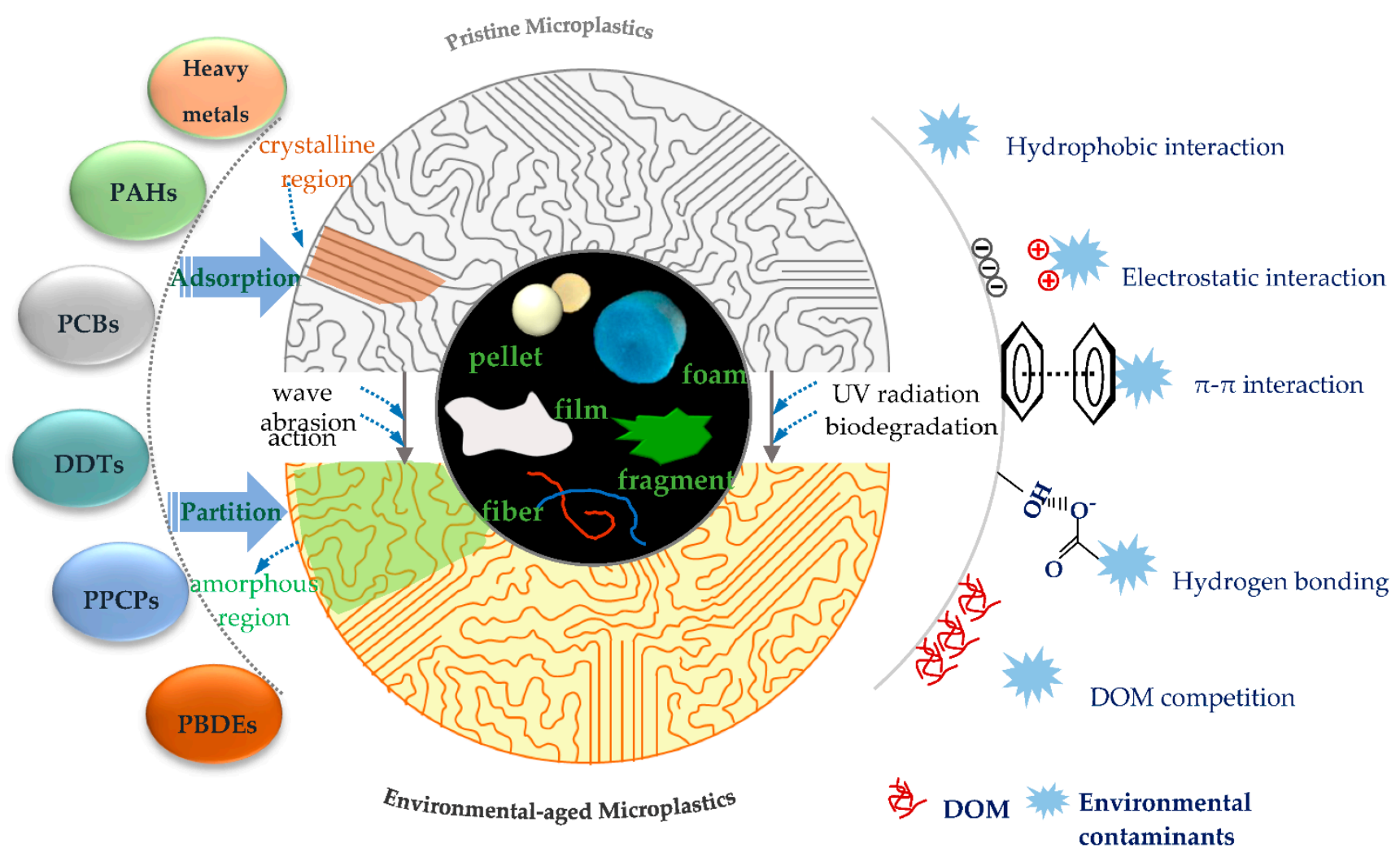

Figure 3. Schematic description of the interaction and mechanisms between environmental contaminants with microplastics.

Once released into environment, plastics will undergo the multiple weathering processes to form the aged microplastics due to the mechanical abrasion, wave action, UV radiation, biodegradation and so on [188]. High levels of organic and metal pollutants on environmental-collected microplastics proved the important role of these aged microplastics as contaminants sink [165-171]. During the weathering process, wrinkles and cracks will be formed on microplastics, increasing the surface roughness and surface area [189], which allows pollutants to effectively diffuse and adsorb in microplastics through the fine cracks [190]. A large amount of oxygen-containing functional groups (e.g., carbonyl and hydroxyl groups) are also introduced on aged microplastics [190], which may increase the polarity and the adsorption affinity for hydrophilic compounds and heavy metals [189,191]. However, a lower adsorption of hydrophobic pollutants on aged microplastics was also reported compared with the pristine particles [192]. Liu et al. investigated the aging behaviors of microplastics under simulated advanced oxidation conditions and found that the aging degree and properties of microplastics closely related with the adsorption behaviors [193]. We note that the environmental behaviors of aged microplastics that resulted from biofouling, microbial degradation, and other weathering processes are rarely studied. Upon the release of microplastics to the water and/or sediment environment, biofilms quickly form on their surfaces (taking place in minutes to hours), which can influence the adsorption processes of microplastics [194]. Biofilms can act as a potential adsorptive phase because of the presence of extracellular polymeric substances such as polysaccharides, proteins, lipids, and other biopolymers. For example, Johansen et al. found that biofilms enhanced the adsorption of strong and weak cations $\left({ }^{137} \mathrm{Cs}\right.$ and $\left.{ }^{90} \mathrm{Sr}\right)$ onto microplastics, revealing that microplastics could be viewed as a potential sink for the environmental radiotracers [195]. However, biofilms can also act a barrier for the diffusive uptake and release of chemicals by increasing the resistance for mass transfer into and out of the microplastics [194]. Therefore, more knowledge on the multiple weathering factors on the properties of microplastics and their resulting adsorption interactions with pollutants still need further clarification. 
In addition to the above influencing factors, the adsorption of contaminants by microplastics is highly affected by environmental aquatic chemistry, which has been studied a lot. Normally, $\mathrm{pH}$ has no significant effect on the adsorption of weak/non-polar hydrophobic compounds by microplastics $[173,174,196]$. However, the adsorption of hydrophilic contaminants by microplastics may change $[140,174,179,197]$, because the solubility and dissociation of these chemicals is $\mathrm{pH}$-dependent, which will influence the hydrophobic and electrostatic interactions with microplastics. Salinity can also affect the adsorption behavior of microplastics but with different results. Compared with that of freshwater, the adsorption capacity in seawater was enhanced for triclosan, perfluorooctanesulfonate, phthalate esters, and PCBs by microplastics $[173,174,180,198]$, which might be due to the salting-out effect as the solubility of these weak/non-polar contaminants was decreased. However, a decreased adsorption capacity of microplastics with increasing the solution salinity to a certain extent was also reported for some hydrophilic compounds (e.g., antibiotics) $[179,184,189,199]$. The competition of cations for the adsorption sites on microplastics was reported to be the main reason, which reduced the electrostatic or H-binding interactions between organic contaminants and microplastics. Considering the above contradictory results, no significant effects of salinity on the adsorption capacity of microplastics have also been reported $[140,185,196,198,200,201]$. It seems that the influence of salinity highly depends on the properties of contaminants, which merits deep investigations. Similar to $\mathrm{pH}$ and salinity, the ubiquitous dissolved organic matter (DOM) presented similar effects on the adsorption capacity of microplastics. Commonly, DOM has adverse effects on the adsorption capacity of microplastics $[140,180,196,198,201,202]$. DOM could interact with microplastics via $\pi-\pi$ conjugation, carboxyl groups, and $\mathrm{C}=\mathrm{O}$ bonds to form a conjugated co-polymer with an elevated electron density [203], which decreased the adsorption of other organic compounds through competition for the adsorption sites. It should be noted that the adsorbed DOM might also interact with pollutants, which may counteract or even exceed the negative effects. For example, humic acid had no significant effects on the adsorption of sulfamethoxazole and phthalate esters by microplastics [173,200], while Zhang et al. observed that humic acid promoted the adsorption of oxytetracycline by microplastics through enhancing the electrostatic interaction [197]. Thereby, the role of DOM on the interactions between contaminants and microplastics needs more attention.

The desorption of chemicals from microplastics is critically important for assessing the role of microplastics as transport vector of contaminants. The reversible desorption of contaminants from microplastics implies the potential release of these chemicals once uptaken by organisms, while irreversible desorption (or desorption hysteresis) will make microplastics as the pollutant sinks. Desorption hysteresis more likely occurs on glassy microplastics than rubbery microplastics. As stated before, the rubbery domains were flexible and highly accessible for chemicals, while the molecular chain segments in glassy domains were more condensed and crosslinked. The adsorption in glassy polymers was affected by both partition and pore filling, and the latter was responsible for desorption hysteresis. Thus, Zuo et al. observed significant desorption hysteresis of phenanthrene from glassy PS but no hysteresis on 100\% rubbery biodegradable poly(butylene adipate co-terephtalate) microplastics [204]. Liu et al. found that PS nanoparticles enhanced the transport of weak/non-polar chemicals in saturated soil but had no effects on polar compounds, and they proved that the desorption hysteresis of weak/non-polar chemicals from the dense and glassy PS was the main reason [187]. Due to the potential contribution of ingested microplastics to the transfer of contaminants into organisms, the desorption of chemicals in simulated gut conditions has also been studied. Bakir et al. reported that the desorption of POPs was enhanced by the gut surfactant, which reached up to 30 times higher than that in seawater [205]. A similar high and fast desorption of PCBs in artificial gut solution was also observed, but the steady-state bioaccumulation factor was predicted to decrease with the increasing ingestion of microplastics, which suggested that the ingested microplastics might play a dilution role for contaminants. However, the authors also pointed out that the desorption of plastic additives might increase the potential 
accumulation of these chemicals [206]. The latest study conducted by Coffin reported that the known butylbenzyl phthalate desorbed in fish gut condition was 1.3 times higher than that in fish control, but the increase in biological estrogenicity by gut condition was 5.1 times higher than the control, which also proved that the contribution was significant by the desorbed uncharacterized plastic additives [149].

\section{Conclusions}

In recent years, microplastics as emerging contaminants have attracted much public attention. This review article summarized the current status of microplastics in the marine environment. The sampling methods were first described, and the identification methods including FTIR, Raman, pyrolysis/TGA-GC-MS, and other novel ways were compared to provide the researchers with the proper one to apply. Through reviewing the literature on survey studies, microplastics were found to be globally distributed in surface water, depth water, sediment, and even the Polar regions. The abundance of microplastics in WWTPs was further analyzed, indicating the important contribution of WWTPs for marine microplastics. What is more, microplastics have also been detected in field-caught and cultured marine organisms, which may bring potential risks to human. Then, the effects of microplastics on marine animals and microalgae, the trophic transfer of microplastics in marine food webs, and the joint toxicity of microplastics were assessed. Microplastics posed negative effects on marine organisms from the individual level to cellular level and even to the genetic level. The food chain transfers of microplastics and their joint toxicity were also observed even though some studies found that certain organisms might egest microplastics out after ingestion. Finally, the interactions between microplastics and environmental contaminants were systematically explored, which were controlled by the inherent properties of microplastics, nature of chemicals, and the environmental chemistry factors. Although the current studies on marine microplastics are developing quickly, research on the above aspects is still at the preliminary stage. For better understanding the environmental fate of microplastics, the following works should be addressed in the future:

(1) The current methods for the sampling and identification of microplastics need to be standardized. Efficient and adequate methods should be developed for the in-situ detection of microplastics.

(2) Although we have gained some information on the distribution and abundance of microplastics, it is still not sufficient for the global regions. More survey studies are still needed to enrich the database of microplastics pollution.

(3) As an important source for marine microplastics, investigation on the terrestrial pollution is not enough, especially for the WWTPs that we pointed out previously. Thus, the fate and transport of microplastics in WWTPs needs further study, and the microplastics-targeted treatment methods urgently need to be developed for reducing the amount of microplastics released from WWTPs to the environment.

(4) There are not yet adequate studies on the impact of microplastics to microalgae, the marine environmental producer, which still need more research from the population level to the genetic level. In addition to the low trophic level organisms, the potential transfer of microplastics and the related contaminants from seafood products to human should also be carefully evaluated.

(5) Considering the role of microplastics as vectors to transport pollutants, the chemicals adsorbed on environmentally collected microplastics should be analyzed to explore the formation of the microplastics-contaminants complex. Systematic studies are also needed to clarify the adsorption and desorption mechanisms of various chemicals on microplastics.

Supplementary Materials: The following are available online at https: / www.mdpi.com/article / 10.3390/w13121713/s1, Figure S1: Sampling technologies and methods of processing, Table S1: Advantages and disadvantages of the identification and quantification methods for microplastics. 
Author Contributions: Conceptualization, F.-F.L. and G.-Z.L.; methodology, S.-C.W. and Z.-L.Z.; software, S.-C.W. and Z.-L.Z.; validation, F.-F.L., S.-C.W., Z.-L.Z. and G.-Z.L.; formal analysis, F.-F.L., S.-C.W., Z.-L.Z. and G.-Z.L.; investigation, S.-C.W. and Z.-L.Z.; resources, S.-C.W. and Z.-L.Z.; data curation, S.-C.W. and Z.-L.Z.; writing-original draft preparation, S.-C.W. and Z.-L.Z.; writingreview and editing, F.-F.L.; visualization, F.-F.L., S.-C.W. and Z.-L.Z.; supervision, F.-F.L.; project administration, F.-F.L.; funding acquisition, F.-F.L. All authors have read and agreed to the published version of the manuscript.

Funding: This research was funded by the National Natural Science Foundation of China-Shandong Joint Fund (U1906224), the Natural Science Foundation of Shandong Province (ZR2020MD114), Young Scholars Program of Shandong University and Shandong University Interdisciplinary Research and Innovation Team of Young Scholars (2020QNQT20).

Institutional Review Board Statement: Not applicable.

Informed Consent Statement: Not applicable.

Data Availability Statement: No new data were created or analyzed in this study. Data sharing is not applicable to this article.

Conflicts of Interest: The authors declare no conflict of interest.

\section{References}

1. Andrady, A.L.; Neal, M.A. Applications and societal benefits of plastics. Philos. Trans. R. Soc. Lond. Ser. B Biol. Sci. 2009, 364, 1977-1984. [CrossRef] [PubMed]

2. Hopewell, J.; Dvorak, R.; Kosior, E. Plastics recycling: Challenges and opportunities. Philos. Trans. R. Soc. Lond. Ser. B Biol. Sci. 2009, 364, 2115-2126. [CrossRef]

3. Kaposi, K.L.; Mos, B.; Kelaher, B.; Dworjanyn, S. Ingestion of microplastic has limited impact on a marine larva. Environ. Sci. Technol. 2014, 48, 1638-1645. [CrossRef]

4. Horton, A.A.; Walton, A.; Spurgeon, D.J.; Lahive, E.; Svendsen, C. Microplastics in freshwater and terrestrial environments: Evaluating the current understanding to identify the knowledge gaps and future research priorities. Sci. Total Environ. 2017, 586, 127-141. [CrossRef]

5. McCormick, A.; Hoellein, T.J.; Mason, S.A.; Schluep, J.; Kelly, J. Microplastic is an abundant and distinct microbial habitat in an urban river. Environ. Sci. Technol. 2014, 48, 11863-11871. [CrossRef]

6. Imhof, H.K.; Laforsch, C.; Wiesheu, A.C.; Schmid, J.; Anger, P.M.; Niessner, R.; Ivleva, N.P. Pigments and plastic in limnetic ecosystems: A qualitative and quantitative study on microparticles of different size classes. Water Res. 2016, 98, 64-74. [CrossRef] [PubMed]

7. Verster, C.; Minnaar, K.; Bouwman, H. Marine and freshwater microplastic research in South Africa. Integr. Environ. Assess. Manag. 2017, 13, 533-535. [CrossRef] [PubMed]

8. Imhof, H.; Ivleva, N.P.; Schmid, J.; Niessner, R.; Laforsch, C. Contamination of beach sediments of a subalpine lake with microplastic particles. Curr. Biol. 2013, 23, R867-R868. [CrossRef]

9. Schoof, R.A.; DeNike, J. Microplastics in the context of regulation of commercial shellfish aquaculture operations. Integr. Environ. Assess. Manag. 2017, 13, 522-527. [CrossRef]

10. Peng, J.; Wang, J.; Cai, L. Current understanding of microplastics in the environment: Occurrence, fate, risks, and what we should do. Integr. Environ. Assess. Manag. 2017, 13, 476-482. [CrossRef] [PubMed]

11. Murphy, F.; Ewins, C.; Carbonnier, F.; Quinn, B. Wastewater treatment works (WwTW) as a source of microplastics in the aquatic environment. Environ. Sci. Technol. 2016, 50, 5800-5808. [CrossRef] [PubMed]

12. Betts, K. Why small plastic particles may pose a big problem in the oceans. Environ. Sci. Technol. 2008, 42, 8995. [CrossRef]

13. Ladewig, S.; Bao, S.; Chow, A.T. Natural fibers: A missing link to chemical pollution dispersion in aquatic environments. Environ. Sci. Technol. 2015, 49, 12609-12610. [CrossRef]

14. Hidalgo-Ruz, V.; Gutow, L.; Thompson, R.C.; Thiel, M. Microplastics in the marine environment: A review of the methods used for identification and quantification. Environ. Sci. Technol. 2012, 46, 3060-3075. [CrossRef]

15. Cole, M.; Lindeque, P.; Fileman, E.; Halsband, C.; Goodhead, R.; Moger, J.; Galloway, T.S. Microplastic ingestion by zooplankton. Environ. Sci. Technol. 2013, 47, 6646-6655. [CrossRef]

16. Roy, P.K.; Hakkarainen, M.; Varma, I.K.; Albertsson, A.-C. Degradable polyethylene: Fantasy or reality. Environ. Sci. Technol. 2011, 45, 4217-4227. [CrossRef] [PubMed]

17. Hartmann, N.B.; Rist, S.; Bodin, J.; Jensen, L.H.S.; Schmidt, S.N.; Mayer, P.; Meibom, A.; Baun, A. Microplastics as vectors for environmental contaminants: Exploring sorption, desorption, and transfer to biota. Integr. Environ. Assess. Manag. 2017, 13, 488-493. [CrossRef]

18. Gray, A.D.; Weinstein, J.E. Size- and shape-dependent effects of microplastic particles on adult daggerblade grass shrimp (Palaemonetes pugio). Environ. Toxicol. Chem. 2017, 36, 3074-3080. [CrossRef] 
19. Haghi, B.N.; Banaee, M. Effects of micro-plastic particles on paraquat toxicity to common carp (Cyprinus carpio): Biochemical changes. Int. J. Environ. Res. 2017, 14, 521-530.

20. Kolandhasamy, P.; Su, L.; Li, J.; Qu, X.; Jabeen, K.; Shi, H. Adherence of microplastics to soft tissue of mussels: A novel way to uptake microplastics beyond ingestion. Sci. Total Environ. 2018, 610-611, 635-640. [CrossRef]

21. Ribeiro, F.; Garcia, A.R.; Pereira, B.P.; Fonseca, M.; Mestre, N.C.; Fonseca, T.G.; Ilharco, L.; Bebianno, M.J. Microplastics effects in Scrobicularia plana. Mar. Pollut. Bull. 2017, 122, 379-391. [CrossRef]

22. Deng, X.-Y.; Hu, X.-L.; Cheng, J.; Ma, Z.-X.; Gao, K. Growth inhibition and oxidative stress induced by 1-octyl-3methylimidazolium bromide on the marine diatom Skeletonema costatum. Ecotoxicol. Environ. Saf. 2016, 132, $170-177$. [CrossRef] [PubMed]

23. Kwon, J.H.; Chang, S.; Hong, S.H.; Shim, W.J. Microplastics as a vector of hydrophobic contaminants: Importance of hydrophobic additives. Integr. Environ. Assess. Manag. 2017, 13, 494-499. [CrossRef]

24. Esiukova, E. Plastic pollution on the Baltic beaches of Kaliningrad region, Russia. Mar. Pollut. Bull. 2017, 114, 1072-1080. [CrossRef]

25. Enders, K.; Lenz, R.; Stedmon, C.A.; Nielsen, T.G. Abundance, size and polymer composition of marine microplastics $\geq 10 \mu \mathrm{m}$ in the Atlantic Ocean and their modelled vertical distribution. Mar. Pollut. Bull. 2015, 100, 70-81. [CrossRef]

26. Collignon, A.; Hecq, J.-H.; Galgani, F.; Voisin, P.; Collard, F.; Goffart, A. Neustonic microplastic and zooplankton in the North Western Mediterranean Sea. Mar. Pollut. Bull. 2012, 64, 861-864. [CrossRef]

27. Vianello, A.; Boldrin, A.; Guerriero, P.; Moschino, V.; Rella, R.; Sturaro, A.; Da Ros, L. Microplastic particles in sediments of Lagoon of Venice, Italy: First observations on occurrence, spatial patterns and identification. Estuar. Coast. Shelf Sci. 2013, 130, 54-61. [CrossRef]

28. Eriksen, M.; Maximenko, N.; Thiel, M.; Cummins, A.; Lattin, G.; Wilson, S.; Hafner, J.; Zellers, A.; Rifman, S. Plastic pollution in the South Pacific subtropical gyre. Mar. Pollut. Bull. 2013, 68, 71-76. [CrossRef] [PubMed]

29. Potthoff, A.; Oelschlägel, K.; Schmitt-Jansen, M.; Rummel, C.D.; Kühnel, D. From the sea to the laboratory: Characterization of microplastic as prerequisite for the assessment of ecotoxicological impact. Integr. Environ. Assess. Manag. 2017, 13, 500-504. [CrossRef]

30. Fisner, M.; Majer, A.P.; Balthazar-Silva, D.; Gorman, D.; Turra, A. Quantifying microplastic pollution on sandy beaches: The conundrum of large sample variability and spatial heterogeneity. Environ. Sci. Pollut. Res. 2017, 24, 13732-13740. [CrossRef]

31. Käppler, A.; Fischer, D.; Oberbeckmann, S.; Schernewski, G.; Labrenz, M.; Eichhorn, K.-J.; Voit, B. Analysis of environmental microplastics by vibrational microspectroscopy: FTIR, Raman or both? Anal. Bioanal. Chem. 2016, 408, 8377-8391. [CrossRef]

32. Oßmann, B.E.; Sarau, G.; Schmitt, S.W.; Holtmannspötter, H.; Christiansen, S.; Dicke, W. Development of an optimal filter substrate for the identification of small microplastic particles in food by micro-Raman spectroscopy. Anal. Bioanal. Chem. 2017, 409, 4099-4109. [CrossRef]

33. Fries, E.; Dekiff, J.H.; Willmeyer, J.; Nuelle, M.-T.; Ebert, M.; Remy, D. Identification of polymer types and additives in marine microplastic particles using pyrolysis-GC/MS and scanning electron microscopy. Environ. Sci. Proc. Impacts 2013, 15, 1949-1956. [CrossRef] [PubMed]

34. Fischer, M.; Scholz-Böttcher, B.M. Simultaneous trace identification and quantification of common types of microplastics in environmental samples by pyrolysis-gas chromatography-mass spectrometry. Environ. Sci. Technol. 2017, 51, 5052-5060. [CrossRef] [PubMed]

35. Dümichen, E.; Barthel, A.-K.; Braun, U.; Bannick, C.G.; Brand, K.; Jekel, M.; Senz, R. Analysis of polyethylene microplastics in environmental samples, using a thermal decomposition method. Water Res. 2015, 85, 451-457. [CrossRef]

36. Wang, L.; Zhang, J.; Hou, S.; Sun, H. A simple method for quantifying polycarbonate and polyethylene terephthalate microplastics in environmental samples by liquid chromatography-tandem mass spectrometry. Environ. Sci. Technol. Lett. 2017, 4, 530-534. [CrossRef]

37. Boucher, J.; Friot, D. Primary Microplastics in the Oceans: A global Evaluation of Sources; IUCN: Gland, Switzerland, 2017.

38. Carr, S.A. Sources and dispersive modes of micro-fibers in the environment. Integr. Environ. Assess. Manag. 2017, 13, 466-469. [CrossRef]

39. Cesa, F.S.; Turra, A.; Baruque-Ramos, J. Synthetic fibers as microplastics in the marine environment: A review from textile perspective with a focus on domestic washings. Sci. Total Environ. 2017, 598, 1116-1129. [CrossRef] [PubMed]

40. Rochman, C.M.; Kross, S.M.; Armstrong, J.B.; Bogan, M.T.; Darling, E.S.; Green, S.J.; Smyth, A.R.; Veríssimo, D. Scientific evidence supports a ban on microbeads. Environ. Sci. Technol. 2015, 49, 10759-10761. [CrossRef] [PubMed]

41. Carr, S.A.; Liu, J.; Tesoro, A.G. Transport and fate of microplastic particles in wastewater treatment plants. Water Res. 2016, 91, 174-182. [CrossRef] [PubMed]

42. Jambeck, J.R.; Geyer, R.; Wilcox, C.; Siegler, T.R.; Perryman, M.; Andrady, A.; Narayan, R.; Law, K.L. Plastic waste inputs from land into the ocean. Science 2015, 347, 768-771. [CrossRef]

43. Li, J.; Liu, H.; Chen, J.P. Microplastics in freshwater systems: A review on occurrence, environmental effects, and methods for microplastics detection. Water Res. 2018, 137, 362-374. [CrossRef]

44. Welden, N.A.; Cowie, P.R. Degradation of common polymer ropes in a sublittoral marine environment. Mar. Pollut. Bull. 2017, 118, 248-253. [CrossRef]

45. Andrady, A.L. Microplastics in the marine environment. Mar. Pollut. Bull. 2011, 62, 1596-1605. [CrossRef] 
46. Song, Y.K.; Hong, S.H.; Jang, M.; Han, G.M.; Jung, S.W.; Shim, W.J. Combined effects of UV exposure duration and mechanical abrasion on microplastic fragmentation by polymer type. Environ. Sci. Technol. 2017, 51, 4368-4376. [CrossRef] [PubMed]

47. Davidson, T.M. Boring crustaceans damage polystyrene floats under docks polluting marine waters with microplastic. Mar. Pollut. Bull. 2012, 64, 1821-1828. [CrossRef]

48. Welden, N.A.; Lusher, A.L. Impacts of changing ocean circulation on the distribution of marine microplastic litter. Integr. Environ. Assess. Manag. 2017, 13, 483-487. [CrossRef] [PubMed]

49. Auta, H.S.; Emenike, C.U.; Fauziah, S.H. Distribution and importance of microplastics in the marine environment: A review of the sources, fate, effects, and potential solutions. Environ. Int. 2017, 102, 165-176. [CrossRef]

50. Suaria, G.; Avio, C.G.; Mineo, A.; Lattin, G.L.; Magaldi, M.G.; Belmonte, G.; Moore, C.J.; Regoli, F.; Aliani, S. The Mediterranean plastic soup: Synthetic polymers in Mediterranean surface waters. Sci. Rep. 2016, 6, 37551. [CrossRef]

51. Frère, L.; Paul-Pont, I.; Rinnert, E.; Petton, S.; Jaffré, J.; Bihannic, I.; Soudant, P.; Lambert, C.; Huvet, A. Influence of environmental and anthropogenic factors on the composition, concentration and spatial distribution of microplastics: A case study of the Bay of Brest (Brittany, France). Environ. Pollut. 2017, 225, 211-222. [CrossRef] [PubMed]

52. Gündoğdu, S.; Çevik, C. Micro- and mesoplastics in Northeast Levantine coast of Turkey: The preliminary results from surface samples. Mar. Pollut. Bull. 2017, 118, 341-347. [CrossRef]

53. Sutton, R.; Mason, S.A.; Stanek, S.K.; Willis-Norton, E.; Wren, I.F.; Box, C. Microplastic contamination in the San Francisco Bay, California, USA. Mar. Pollut. Bull. 2016, 109, 230-235. [CrossRef] [PubMed]

54. Gewert, B.; Ogonowski, M.; Barth, A.; MacLeod, M. Abundance and composition of near surface microplastics and plastic debris in the Stockholm Archipelago, Baltic Sea. Mar. Pollut. Bull. 2017, 120, 292-302. [CrossRef] [PubMed]

55. Song, Y.K.; Hong, S.H.; Eo, S.; Jang, M.; Han, G.M.; Isobe, A.; Shim, W.J. Horizontal and vertical distribution of microplastics in Korean coastal waters. Environ. Sci. Technol. 2018, 52, 12188-12197. [CrossRef]

56. Free, C.M.; Jensen, O.P.; Mason, S.A.; Eriksen, M.; Williamson, N.J.; Boldgiv, B. High-levels of microplastic pollution in a large, remote, mountain lake. Mar. Pollut. Bull. 2014, 85, 156-163. [CrossRef]

57. Anderson, P.J.; Warrack, S.; Langen, V.; Challis, J.K.; Hanson, M.L.; Rennie, M.D. Microplastic contamination in Lake Winnipeg, Canada. Environ. Pollut. 2017, 225, 223-231. [CrossRef] [PubMed]

58. Lares, M.; Ncibi, M.C.; Sillanpää, M.; Sillanpää, M. Occurrence, identification and removal of microplastic particles and fibers in conventional activated sludge process and advanced MBR technology. Water Res. 2018, 133, 236-246. [CrossRef] [PubMed]

59. Mintenig, S.; Int-Veen, I.; Löder, M.; Primpke, S.; Gerdts, G. Identification of microplastic in effluents of waste water treatment plants using focal plane array-based micro-Fourier-transform infrared imaging. Water Res. 2017, 108, 365-372. [CrossRef]

60. Ziajahromi, S.; Neale, P.A.; Rintoul, L.; Leusch, F.D.L. Wastewater treatment plants as a pathway for microplastics: Development of a new approach to sample wastewater-based microplastics. Water Res. 2017, 112, 93-99. [CrossRef]

61. Kanhai, L.D.K.; Officer, R.; Lyashevska, O.; Thompson, R.C.; O'Connor, I. Microplastic abundance, distribution and composition along a latitudinal gradient in the Atlantic Ocean. Mar. Pollut. Bull. 2017, 115, 307-314. [CrossRef]

62. Peng, G.; Zhu, B.; Yang, D.; Su, L.; Shi, H.; Li, D. Microplastics in sediments of the Changjiang Estuary, China. Environ. Pollut. 2017, 225, 283-290. [CrossRef]

63. Claessens, M.; Meester, S.D.; Landuyt, L.V.; Clerck, K.D.; Janssen, C.R. Occurrence and distribution of microplastics in marine sediments along the Belgian coast. Mar. Pollut. Bull. 2011, 62, 2199-2204. [CrossRef]

64. Alomar, C.; Deudero, S. Evidence of microplastic ingestion in the shark Galeus melastomus Rafinesque, 1810 in the continental shelf off the western Mediterranean Sea. Environ. Pollut. 2017, 223, 223-229. [CrossRef] [PubMed]

65. Halstead, J.E.; Smith, J.A.; Carter, E.A.; Lay, P.A.; Johnston, E.L. Assessment tools for microplastics and natural fibres ingested by fish in an urbanised estuary. Environ. Pollut. 2018, 234, 552-561. [CrossRef]

66. Li, J.; Green, C.; Reynolds, A.; Shi, H.; Rotchell, J.M. Microplastics in mussels sampled from coastal waters and supermarkets in the United Kingdom. Environ. Pollut. 2018, 241, 35-44. [CrossRef] [PubMed]

67. Naji, A.; Nuri, M.; Vethaak, A.D. Microplastics contamination in molluscs from the northern part of the Persian Gulf. Environ. Pollut. 2018, 235, 113-120. [CrossRef]

68. Mohsen, M.; Wang, Q.; Zhang, L.; Sun, L.; Lin, C.; Yang, H. Microplastic ingestion by the farmed sea cucumber Apostichopus japonicus in China. Environ. Pollut. 2019, 245, 1071-1078. [CrossRef]

69. Teng, J.; Wang, Q.; Ran, W.; Wu, D.; Liu, Y.; Sun, S.; Liu, H.; Cao, R.; Zhao, J. Microplastic in cultured oysters from different coastal areas of China. Sci. Total Environ. 2019, 653, 1282-1292. [CrossRef]

70. Lima, A.R.A.; Costa, M.F.; Barletta, M. Distribution patterns of microplastics within the plankton of a tropical estuary. Environ. Res. 2014, 132, 146-155. [CrossRef] [PubMed]

71. Van Cauwenberghe, L.; Vanreusel, A.; Mees, J.; Janssen, C.R. Microplastic pollution in deep-sea sediments. Environ. Pollut. 2013, 182, 495-499. [CrossRef]

72. Courtene-Jones, W.; Quinn, B.; Gary, S.F.; Mogg, A.O.; Narayanaswamy, B.E. Microplastic pollution identified in deep-sea water and ingested by benthic invertebrates in the Rockall Trough, North Atlantic Ocean. Environ. Pollut. 2017, 231, 271-280. [CrossRef] [PubMed]

73. Carreras-Colom, E.; Constenla, M.; Soler-Membrives, A.; Cartes, J.E.; Baeza, M.; Padrós, F.; Carrassón, M. Spatial occurrence and effects of microplastic ingestion on the deep-water shrimp Aristeus antennatus. Mar. Pollut. Bull. 2018, 133, 44-52. [CrossRef] 
74. Canniff, P.M.; Hoang, T.C. Microplastic ingestion by Daphnia magna and its enhancement on algal growth. Sci. Total Environ. 2018, 633, 500-507. [CrossRef] [PubMed]

75. Cole, M.; Galloway, T.S. Ingestion of nanoplastics and microplastics by Pacific oyster larvae. Environ. Sci. Technol. 2015, 49, 14625-14632. [CrossRef]

76. Ory, N.C.; Gallardo, C.; Lenz, M.; Thiel, M. Capture, swallowing, and egestion of microplastics by a planktivorous juvenile fish. Environ. Pollut. 2018, 240, 566-573. [CrossRef]

77. Ašmonaitè, G.; Sundh, H.; Asker, N.; Almroth, B.M.C. Rainbow trout maintain intestinal transport and barrier functions following exposure to polystyrene microplastics. Environ. Sci. Technol. 2018, 52, 14392-14401. [CrossRef]

78. Dawson, A.; Huston, W.; Kawaguchi, S.; King, C.; Cropp, R.; Wild, S.; Eisenmann, P.; Townsend, K.; Bengtson Nash, S. Uptake and depuration kinetics influence microplastic bioaccumulation and toxicity in Antarctic krill (Euphausia superba). Environ. Sci. Technol. 2018, 52, 3195-3201. [CrossRef]

79. Cole, M.; Lindeque, P.; Fileman, E.; Halsband, C.; Galloway, T.S. The impact of polystyrene microplastics on feeding, function and fecundity in the marine copepod Calanus helgolandicus. Environ. Sci. Technol. 2015, 49, 1130-1137. [CrossRef] [PubMed]

80. Lee, K.-W.; Shim, W.J.; Kwon, O.Y.; Kang, J.-H. Size-dependent effects of micro polystyrene particles in the marine copepod Tigriopus japonicus. Environ. Sci. Technol. 2013, 47, 11278-11283. [CrossRef]

81. Gardon, T.; Reisser, C.; Soyez, C.; Quillien, V.; Le Moullac, G. Microplastics affect energy balance and gametogenesis in the pearl oyster Pinctada margaritifera. Environ. Sci. Technol. 2018, 52, 5277-5286. [CrossRef] [PubMed]

82. Von Moos, N.; Burkhardt-Holm, P.; Köhler, A. Uptake and effects of microplastics on cells and tissue of the blue mussel Mytilus edulis L. after an experimental exposure. Environ. Sci. Technol. 2012, 46, 11327-11335. [CrossRef]

83. Lu, Y.; Zhang, Y.; Deng, Y.; Jiang, W.; Zhao, Y.; Geng, J.; Ding, L.; Ren, H. Uptake and accumulation of polystyrene microplastics in zebrafish (Danio rerio) and toxic effects in liver. Environ. Sci. Technol. 2016, 50, 4054-4060. [CrossRef]

84. Jeong, C.-B.; Won, E.-J.; Kang, H.-M.; Lee, M.-C.; Hwang, D.-S.; Hwang, U.-K.; Zhou, B.; Souissi, S.; Lee, S.-J.; Lee, J.-S. Microplastic size-dependent toxicity, oxidative stress induction, and p-JNK and p-p38 activation in the monogonont rotifer (Brachionus koreanus). Environ. Sci. Technol. 2016, 50, 8849-8857. [CrossRef]

85. Tang, J.; Ni, X.; Zhou, Z.; Wang, L.; Lin, S. Acute microplastic exposure raises stress response and suppresses detoxification and immune capacities in the scleractinian coral Pocillopora damicornis. Environ. Pollut. 2018, 243, 66-74. [CrossRef] [PubMed]

86. Watts, A.J.R.; Urbina, M.M.A.; Goodhead, R.M.; Moger, J.; Lewis, C.; Galloway, T.S. Effect of microplastic on the gills of the shore crab Carcinus maenas. Environ. Sci. Technol. 2016, 50, 5364-5369. [CrossRef] [PubMed]

87. Della Torre, C.; Bergami, E.; Salvati, A.; Faleri, C.; Cirino, P.; Dawson, K.A.; Corsi, I. Accumulation and embryotoxicity of polystyrene nanoparticles at early stage of development of sea urchin embryos Paracentrotus lividus. Environ. Sci. Technol. 2014, 48, 12302-12311. [CrossRef]

88. Luan, L.; Wang, X.; Zheng, H.; Liu, L.; Luo, X.; Li, F. Differential toxicity of functionalized polystyrene microplastics to clams (Meretrix meretrix) at three key development stages of life history. Mar. Pollut. Bull. 2019, 139, 346-354. [CrossRef] [PubMed]

89. Kim, D.; Chae, Y.; An, Y.-J. Mixture toxicity of nickel and microplastics with different functional groups on Daphnia magna. Environ. Sci. Technol. 2017, 51, 12852-12858. [CrossRef]

90. Sun, B.; Hu, Y.; Cheng, H.; Tao, S. Releases of brominated flame retardants (BFRs) from microplastics in aqueous medium: Kinetics and molecular-size dependence of diffusion. Water Res. 2019, 151, 215-225. [CrossRef]

91. Li, H.-X.; Getzinger, G.J.; Ferguson, P.L.; Orihuela, B.; Zhu, M.; Rittschof, D. Effects of toxic leachate from commercial plastics on larval survival and settlement of the barnacle Amphibalanus amphitrite. Environ. Sci. Technol. 2016, 50, 924-931. [CrossRef]

92. Oliviero, M.; Tato, T.; Schiavo, S.; Fernández, V.; Manzo, S.; Beiras, R. Leachates of micronized plastic toys provoke embryotoxic effects upon sea urchin Paracentrotus lividus. Environ. Pollut. 2019, 247, 706-715. [CrossRef]

93. Nobre, C.R.; Santana, M.; Maluf, A.; Cortez, F.; Cesar, A.; Pereira, C.; Turra, A. Assessment of microplastic toxicity to embryonic development of the sea urchin Lytechinus variegatus (Echinodermata: Echinoidea). Mar. Pollut. Bull. 2015, 92, 99-104. [CrossRef] [PubMed]

94. Gandara e Silva, P.P.; Nobre, C.R.; Resaffe, P.; Pereira, C.D.S.; Gusmão, F. Leachate from microplastics impairs larval development in brown mussels. Water Res. 2016, 106, 364-370. [CrossRef] [PubMed]

95. Coffin, S.; Dudley, S.; Taylor, A.; Wolf, D.; Wang, J.; Lee, I.; Schlenk, D. Comparisons of analytical chemistry and biological activities of extracts from North Pacific gyre plastics with UV-treated and untreated plastics using in vitro and in vivo models. Environ. Int. 2018, 121, 942-954. [CrossRef] [PubMed]

96. Yang, W.; Gao, P.; Li, H.; Huang, J.; Zhang, Y.; Ding, H.; Zhang, W. Mechanism of the inhibition and detoxification effects of the interaction between nanoplastics and microalgae Chlorella pyrenoidosa. Sci. Total Environ. 2021, 783, 146919-146929. [CrossRef] [PubMed]

97. Zhu, X.; Zhao, W.; Chen, X.; Zhao, T.; Tan, L.; Wang, J. Growth inhibition of the microalgae Skeletonema costatum under copper nanoparticles with microplastic exposure. Mar. Environ. Res. 2020, 158, 105005-105011. [CrossRef]

98. Wang, Q.; Wangjin, X.; Zhang, Y.; Wang, N.; Wang, Y.; Meng, G.; Chen, Y. The toxicity of virgin and UV-aged PVC microplastics on the growth of freshwater algae Chlamydomonas reinhardtii. Sci. Total Environ. 2020, 749, 141603-141609. [CrossRef]

99. Zhang, C.; Chen, X.H.; Wang, J.T.; Tan, L.J. Toxic effects of microplastic on marine microalgae Skeletonema costatum: Interactions between microplastic and algae. Environ. Pollut. 2017, 220, 1282-1288. [CrossRef] 
100. Zhao, T.; Tan, L.J.; Huang, W.Q.; Wang, J.T. The interactions between micro polyvinyl chloride (mPVC) and marine dinoflagellate Karenia mikimotoi: The inhibition of growth, chlorophyll and photosynthetic efficiency. Environ. Pollut. 2019, 247, 883-889. [CrossRef]

101. Zhao, T.; Tan, L.; Zhu, X.; Huang, W.; Wang, J. Size-dependent oxidative stress effect of nano/micro-scaled polystyrene on Karenia mikimotoi. Mar. Pollut. Bull. 2020, 154, 111074-111084. [CrossRef] [PubMed]

102. Yang, W.; Gao, X.; Wu, Y.; Wan, L.; Tan, L.; Yuan, S.; Ding, H.; Zhang, W. The combined toxicity influence of microplastics and nonylphenol on microalgae Chlorella pyrenoidosa. Ecotoxicol. Environ. Saf. 2020, 195, 110484-110493. [CrossRef]

103. Sjollema, S.B.; Redondo-Hasselerharm, P.; Leslie, H.A.; Kraak, M.H.; Vethaak, A.D. Do plastic particles affect microalgal photosynthesis and growth? Aquat. Toxicol. 2016, 170, 259-261. [CrossRef]

104. González-Fernández, C.; Toullec, J.; Lambert, C.; Le Goïc, N.; Seoane, M.; Moriceau, B.; Huvet, A.; Berchel, M.; Vincent, D.; Courcot, L.; et al. Do transparent exopolymeric particles (TEP) affect the toxicity of nanoplastics on Chaetoceros neogracile? Environ. Pollut. 2019, 250, 873-882. [CrossRef]

105. Zheng, X.; Zhang, W.; Yuan, Y.; Li, Y.; Liu, X.; Wang, X.; Fan, Z. Growth inhibition, toxin production and oxidative stress caused by three microplastics in Microcystis aeruginosa. Ecotoxicol. Environ. Saf. 2021, 208, 111575-111583. [CrossRef]

106. Prata, J.C.; Lavorante, B.R.; Montenegro, M.D.; Guilhermino, C.B.; Guilhermino, L. Influence of microplastics on the toxicity of the pharmaceuticals procainamide and doxycycline on the marine microalgae Tetraselmis chuii. Aquat. Toxicol. 2018, 197, 143-152. [CrossRef] [PubMed]

107. Zhu, Z.-L.; Wang, S.-C.; Zhao, F.-F.; Wang, S.-G.; Liu, F.-F.; Liu, G.-Z. Joint toxicity of microplastics with triclosan to marine microalgae Skeletonema costatum. Environ. Pollut. 2018, 246, 509-517. [CrossRef] [PubMed]

108. Yi, X.; Chi, T.; Li, Z.; Wang, J.; Yu, M.; Wu, M.; Zhou, H. Combined effect of polystyrene plastics and triphenyltin chloride on the green algae Chlorella pyrenoidosa. Environ. Sci. Pollut. Res. 2019, 26, 15011-15018. [CrossRef]

109. Wang, S.; Wang, Y.; Liang, Y.; Cao, W.; Sun, C.; Ju, P.; Zheng, L. The interactions between microplastic polyvinyl chloride and marine diatoms: Physiological, morphological, and growth effects. Ecotoxicol. Environ. Saf. 2020, 203, 111000-111007. [CrossRef] [PubMed]

110. Song, C.; Liu, Z.; Wang, C.; Li, S.; Kitamura, Y. Different interaction performance between microplastics and microalgae: The bioelimination potential of Chlorella sp. L38 and Phaeodactylum tricornutum MASCC-0025. Sci. Total Environ. 2020, 723, 138146-138155. [CrossRef]

111. Li, F.; Liang, Z.; Zheng, X.; Zhao, W.; Wu, M.; Wang, Z. Toxicity of nano- $\mathrm{TiO}_{2}$ on algae and the site of reactive oxygen species production. Aquat Toxicol 2015, 158, 1-13. [CrossRef] [PubMed]

112. Zhang, C.; Chen, X.; Wang, J.; Tan, L. Toxicity of zinc oxide nanoparticles on marine microalgae possessing different shapes and surface structures. Environ. Eng. Sci. 2018, 35, 785-790. [CrossRef]

113. Hu, X.; Ouyang, S.; Mu, L.; An, J.; Zhou, Q. Effects of graphene oxide and oxidized carbon nanotubes on the cellular division, microstructure, uptake, oxidative stress, and metabolic profiles. Environ. Sci. Technol. 2015, 49, 10825-10833. [CrossRef]

114. Dawson, A.L.; Kawaguchi, S.; King, C.K.; Townsend, K.A.; King, R.; Huston, W.M.; Bengtson Nash, S.M. Turning microplastics into nanoplastics through digestive fragmentation by Antarctic krill. Nat. Commun. 2018, 9, 1001. [CrossRef]

115. Da Costa, J.P.; Santos, P.S.; Duarte, A.; Rocha-Santos, T. (Nano)plastics in the environment-Sources, fates and effects. Sci Total Environ. 2016, 566-567, 15-26. [CrossRef] [PubMed]

116. Nichols, E.C.; Lavers, J.L.; Archer-Rand, S.; Bond, A.L. Assessing plastic size distribution and quantity on a remote island in the South Pacific. Mar. Pollut. Bull. 2021, 167, 112366-112374. [CrossRef] [PubMed]

117. Llorca, M.; Vega-Herrera, A.; Schirinzi, G.; Savva, K.; Abad, E.; Farré, M. Screening of suspected micro(nano)plastics in the Ebro Delta (Mediterranean Sea). J. Hazard. Mater. 2021, 404, 124022-124030. [CrossRef] [PubMed]

118. Schwab, F.; Bucheli, T.D.; Lukhele, L.P.; Magrez, A.; Nowack, B.; Sigg, L.; Knauer, K. Are carbon nanotube effects on green algae caused by shading and agglomeration? Environ. Sci Technol. 2011, 45, 6136-6144. [CrossRef]

119. Aruoja, V.; Dubourguier, H.-C.; Kasemets, K.; Kahru, A. Toxicity of nanoparticles of $\mathrm{CuO}, \mathrm{ZnO}$ and $\mathrm{TiO}_{2}$ to microalgae Pseudokirchneriella subcapitata. Sci. Total. Environ. 2009, 407, 1461-1468. [CrossRef] [PubMed]

120. Liu, G.; Jiang, R.; You, J.; Muir, D.C.G.; Zeng, E.Y. Microplastic impacts on microalgae growth: Effects of size and humic acid. Environ. Sci. Technol. 2020, 54, 1782-1789. [CrossRef]

121. Eslick, E.M.; Beilby, M.J.; Moon, A.R. A study of the native cell wall structures of the marine alga Ventricaria ventricosa (Siphonocladales, Chlorophyceae) using atomic force microscopy. Microscopy (Oxf.) 2014, 63, 131-140. [CrossRef] [PubMed]

122. Nolte, T.M.; Hartmann, N.B.; Kleijn, J.M.; Garnaes, J.; van de Meent, D.; Hendriks, A.J.; Baun, A. The toxicity of plastic nanoparticles to green algae as influenced by surface modification, medium hardness and cellular adsorption. Aquat. Toxicol. 2017, 183, 11-20. [CrossRef] [PubMed]

123. Xiao, Y.; Jiang, X.; Liao, Y.; Zhao, W.; Zhao, P.; Li, M. Adverse physiological and molecular level effects of polystyrene microplastics on freshwater microalgae. Chemosphere 2020, 255, 126914-126921. [CrossRef]

124. Shiu, R.-F.; Vazquez, C.I.; Chiang, C.-Y.; Chiu, M.-H.; Chen, C.-S.; Ni, C.-W.; Gong, G.-C.; Quigg, A.; Santschi, P.H.; Chin, W.-C. Nano- and microplastics trigger secretion of protein-rich extracellular polymeric substances from phytoplankton. Sci. Total Environ. 2020, 748, 141469-141478. [CrossRef]

125. Bhattacharya, P.; Lin, S.J.; Turner, J.P.; Ke, P.C. Physical adsorption of charged plastic nanoparticles affects algal photosynthesis. J. Phys. Chem. C 2010, 114, 16556-16561. [CrossRef] 
126. Tang, Y.; Li, S.; Lu, Y.; Li, Q.; Yu, S. The influence of humic acid on the toxicity of nano-ZnO and $\mathrm{Zn}^{2+}$ to the Anabaena sp. Environ. Toxicol. 2015, 30, 895-903. [CrossRef]

127. Liu, Y.; Wang, Z.; Wang, S.; Fang, H.; Ye, N.; Wang, D. Ecotoxicological effects on Scenedesmus obliquus and Danio rerio Co-exposed to polystyrene nano-plastic particles and natural acidic organic polymer. Environ. Toxicol. Pharmacol. 2019, 67, 21-28. [CrossRef]

128. Xia, B.; Chen, B.; Sun, X.; Qu, K.; Ma, F.; Du, M. Interaction of $\mathrm{TiO}_{2}$ nanoparticles with the marine microalga Nitzschia closterium: Growth inhibition, oxidative stress and internalization. Sci. Total Environ. 2015, 508, 525-533. [CrossRef] [PubMed]

129. Wang, S.; Liu, M.; Wang, J.; Huang, J.; Wang, J. Polystyrene nanoplastics cause growth inhibition, morphological damage and physiological disturbance in the marine microalga Platymonas helgolandica. Mar. Pollut. Bull. 2020, 158, 111403-111410. [CrossRef]

130. Mao, Y.F.; Ai, H.N.; Chen, Y.; Zhang, Z.Y.; Zeng, P.; Kang, L.; Li, W.; Gu, W.K.; He, Q.; Li, H. Phytoplankton response to polystyrene microplastics: Perspective from an entire growth period. Chemosphere 2018, 208, 59-68. [CrossRef] [PubMed]

131. Hazeem, L.J.; Yesilay, G.; Bououdina, M.; Perna, S.; Cetin, D.; Suludere, Z.; Barras, A.; Boukherroub, R. Investigation of the toxic effects of different polystyrene micro-and nanoplastics on microalgae Chlorella vulgaris by analysis of cell viability, pigment content, oxidative stress and ultrastructural changes. Mar. Pollut. Bull. 2020, 156, 111278-111287. [CrossRef] [PubMed]

132. Wei, W.; Huang, Q.-S.; Sun, J.; Wang, J.-Y.; Wu, S.-L.; Ni, B.-J. Polyvinyl chloride microplastics affect methane production from the anaerobic digestion of waste activated sludge through leaching toxic bisphenol-A. Environ. Sci. Technol. 2019, 53, $2509-2517$. [CrossRef]

133. Gu, S.; Zheng, H.; Xu, Q.; Sun, C.; Shi, M.; Wang, Z.; Li, F. Comparative toxicity of the plasticizer dibutyl phthalate to two freshwater algae. Aquat. Toxicol. 2017, 191, 122-130. [CrossRef]

134. Luo, H.; Xiang, Y.; He, D.; Li, Y.; Zhao, Y.; Wang, S.; Pan, X. Leaching behavior of fluorescent additives from microplastics and the toxicity of leachate to Chlorella vulgaris. Sci. Total Environ. 2019, 678, 1-9. [CrossRef]

135. Müller, A.; Becker, R.; Dorgerloh, U.; Simon, F.-G.; Braun, U. The effect of polymer aging on the uptake of fuel aromatics and ethers by microplastics. Environ. Pollut. 2018, 240, 639-646. [CrossRef] [PubMed]

136. Mai, L.; Bao, L.-J.; Shi, L.; Liu, L.-Y.; Zeng, E.Y. Polycyclic aromatic hydrocarbons affiliated with microplastics in surface waters of Bohai and Huanghai Seas, China. Environ. Pollut. 2018, 241, 834-840. [CrossRef]

137. Zhao, L.; Rong, L.; Xu, J.; Lian, J.; Wang, L.; Sun, H. Sorption of five organic compounds by polar and nonpolar microplastics. Chemosphere 2020, 257, 127206-127214. [CrossRef]

138. Liu, Z.M.; Qin, Q.D.; Hu, Z.X.; Yan, L.; Ieong, U.I.; Xu, Y. Adsorption of chlorophenols on polyethylene terephthalate microplastics from aqueous environments: Kinetics, mechanisms and influencing factors. Environ. Pollut. 2020, 265, 114926-114935. [CrossRef] [PubMed]

139. Li, J.; Zhang, K.; Zhang, H. Adsorption of antibiotics on microplastics. Environ. Pollut. 2018, 237, 460-467. [CrossRef] [PubMed]

140. Xu, B.; Liu, F.; Brookes, P.C.; Xu, J. Microplastics play a minor role in tetracycline sorption in the presence of dissolved organic matter. Environ. Pollut. 2018, 240, 87-94. [CrossRef] [PubMed]

141. González-Pleiter, M.; Pedrouzo-Rodriguez, A.; Verdú, I.; Leganés, F.; Marco, E.; Rosal, R.; Fernández-Pinas, F. Microplastics as vectors of the antibiotics azithromycin and clarithromycin: Effects towards freshwater microalgae. Chemosphere 2021, 268, 128824-128831. [CrossRef] [PubMed]

142. Ho, W.K.; Law, J.C.; Zhang, T.; Leung, K.S. Effects of weathering on the sorption behavior and toxicity of polystyrene microplastics in multi-solute systems. Water. Res. 2020, 187, 116419-116428. [CrossRef]

143. Farrell, P.; Nelson, K. Trophic level transfer of microplastic: Mytilus edulis (L.) to Carcinus maenas (L.). Environ. Pollut. 2013, 177, 1-3. [CrossRef]

144. Setälä, O.; Fleming-Lehtinen, V.; Lehtiniemi, M. Ingestion and transfer of microplastics in the planktonic food web. Environ. Pollut. 2014, 185, 77-83. [CrossRef]

145. Chagnon, C.; Thiel, M.; Antunes, J.; Ferreira, J.L.; Sobral, P.; Ory, N.C. Plastic ingestion and trophic transfer between Easter Island flying fish (Cheilopogon rapanouiensis) and yellowfin tuna (Thunnus albacares) from Rapa Nui (Easter Island). Environ. Pollut. 2018, 243, 127-133. [CrossRef] [PubMed]

146. Nelms, S.E.; Galloway, T.S.; Godley, B.J.; Jarvis, D.S.; Lindeque, P.K. Investigating microplastic trophic transfer in marine top predators. Environ. Pollut. 2018, 238, 999-1007. [CrossRef] [PubMed]

147. Cedervall, T.; Hansson, L.-A.; Lard, M.; Frohm, B.; Linse, S. Food chain transport of nanoparticles affects behaviour and fat metabolism in fish. PLoS ONE 2012, 7. [CrossRef]

148. Chae, Y.; Kim, D.; Kim, S.W.; An, Y.-J. Trophic transfer and individual impact of nano-sized polystyrene in a four-species freshwater food chain. Sci. Rep. 2018, 8, 284. [CrossRef] [PubMed]

149. Coffin, S.; Huang, G.-Y.; Lee, I.; Schlenk, D. Fish and seabird gut conditions enhance desorption of estrogenic chemicals from commonly-ingested plastic items. Environ. Sci. Technol. 2019, 53, 4588-4599. [CrossRef]

150. Nor, N.H.M.; Koelmans, A.A. Transfer of PCBs from microplastics under simulated gut fluid conditions is biphasic and reversible. Environ. Sci. Technol. 2019, 53, 1874-1883.

151. Batel, A.; Linti, F.; Scherer, M.; Erdinger, L.; Braunbeck, T. Transfer of benzo[a]pyrene from microplastics to Artemia nauplii and further to zebrafish via a trophic food web experiment: CYP1A induction and visual tracking of persistent organic pollutants Environ. Toxicol. Chem. 2016, 35, 1656-1666. [CrossRef] 
152. Diepens, N.J.; Koelmans, A.A. Accumulation of plastic debris and associated contaminants in aquatic food webs. Environ. Sci. Technol. 2018, 52, 8510-8520. [CrossRef] [PubMed]

153. Grigorakis, S.; Drouillard, K.G. Effect of microplastic amendment to food on diet assimilation efficiencies of PCBs by fish. Environ. Sci. Technol. 2018, 52, 10796-10802. [CrossRef]

154. Herzke, D.; Anker-Nilssen, T.; Nøst, T.H.; Götsch, A.; Christensen-Dalsgaard, S.; Langset, M.; Fangel, K.; Koelmans, A.A Negligible impact of ingested microplastics on tissue concentrations of persistent organic pollutants in northern fulmars off coastal Norway. Environ. Sci. Technol. 2016, 50, 1924-1933. [CrossRef]

155. Koelmans, A.A.; Bakir, A.; Burton, G.; Janssen, C.R. Microplastic as a vector for chemicals in the aquatic environment: Critical review and model-supported reinterpretation of empirical studies. Environ. Sci. Technol. 2016, 50, 3315-3326. [CrossRef] [PubMed]

156. Wardrop, P.; Shimeta, J.; Nugegoda, D.; Morrison, P.D.; Miranda, A.; Tang, M.; Clarke, B.O. Chemical pollutants sorbed to ingested microbeads from personal care products accumulate in fish. Environ. Sci. Technol. 2016, 50, 4037-4044. [CrossRef] [PubMed]

157. Oliveira, M.; Ribeiro, A.; Hylland, K.; Guilhermino, L. Single and combined effects of microplastics and pyrene on juveniles (0+ group) of the common goby Pomatoschistus microps (Teleostei, Gobiidae). Ecol. Indic. 2013, 34, 641-647. [CrossRef]

158. Rochman, C.M.; Hoh, E.; Kurobe, T.; Teh, S.J. Ingested plastic transfers hazardous chemicals to fish and induces hepatic stress. Sci. Rep. 2013, 3, 3263. [CrossRef]

159. Rochman, C.M.; Kurobe, T.; Flores, I.; Teh, S.J. Early warning signs of endocrine disruption in adult fish from the ingestion of polyethylene with and without sorbed chemical pollutants from the marine environment. Sci. Total Environ. 2014, 493, 656-661. [CrossRef] [PubMed]

160. Luís, L.G.; Ferreira, P.; Fonte, E.; Oliveira, M.; Guilhermino, L. Does the presence of microplastics influence the acute toxicity of chromium(VI) to early juveniles of the common goby (Pomatoschistus microps)? A study with juveniles from two wild estuarine populations. Aquat. Toxicol. 2015, 164, 163-174. [PubMed]

161. Bakir, A.; O'Connor, I.A.; Rowland, S.J.; Hendriks, A.J.; Thompson, R.C. Relative importance of microplastics as a pathway for the transfer of hydrophobic organic chemicals to marine life. Environ. Pollut. 2016, 219, 56-65. [CrossRef]

162. Beiras, R.; Tato, T. Microplastics do not increase toxicity of a hydrophobic organic chemical to marine plankton. Mar. Pollut. Bull. 2019, 138, 58-62. [CrossRef]

163. Ašmonaitè, G.; Larsson, K.; Undeland, I.; Sturve, J.; Carney Almroth, B. Size matters: Ingestion of relatively large microplastics contaminated with environmental pollutants posed little risk for fish health and fillet quality. Environ. Sci. Technol. 2018, 52, 14381-14391. [CrossRef]

164. Ma, Y.; Huang, A.; Cao, S.; Sun, F.; Wang, L.; Guo, H.; Ji, R. Effects of nanoplastics and microplastics on toxicity, bioaccumulation, and environmental fate of phenanthrene in fresh water. Environ. Pollut. 2016, 219, 166-173. [CrossRef] [PubMed]

165. Antunes, J.C.; Frias, J.G.L.; Micaelo, A.C.; Sobral, P. Resin pellets from beaches of the Portuguese coast and adsorbed persistent organic pollutants. Estuar. Coast. Shelf Sci. 2013, 130, 62-69. [CrossRef]

166. Frias, J.; Sobral, P.; Ferreira, A. Organic pollutants in microplastics from two beaches of the Portuguese coast. Mar. Pollut. Bull. 2010, 60, 1988-1992. [CrossRef] [PubMed]

167. Camacho, M.; Herrera, A.; Gomez, M.; Acosta-Dacal, A.; Martinez, I.; Alberto Henriquez-Hernandez, L.; Luzardo, O.P. Organic pollutants in marine plastic debris from Canary Islands beaches. Sci. Total Environ. 2019, 662, 22-31. [CrossRef] [PubMed]

168. Jasna, M.-L.; Jelena, L.; Pero, T.; Dubravka, B.V.; Jasna, S.; Josko, P. Levels of trace metals on microplastic particles in beach sediments of the island of Vis, Adriatic Sea, Croatia. Mar. Pollut. Bull. 2018, 137, 231-236.

169. Munier, B.; Bendell, L.I. Macro and micro plastics sorb and desorb metals and act as a point source of trace metals to coastal ecosystems. PLoS ONE 2018, 13. [CrossRef] [PubMed]

170. Prunier, J.; Maurice, L.; Perez, E.; Gigault, J.; Wickmann, A.-C.P.; Davranche, M.; ter Halle, A. Trace metals in polyethylene debris from the North Atlantic subtropical gyre. Environ. Pollut. 2019, 245, 371-379. [CrossRef] [PubMed]

171. Vedolin, M.C.; Teophilo, C.Y.S.; Turra, A.; Figueira, R.C.L. Spatial variability in the concentrations of metals in beached microplastics. Mar. Pollut. Bull. 2018, 129, 487-493. [CrossRef] [PubMed]

172. Guo, X.; Wang, X.; Zhou, X.; Kong, X.; Tao, S.; Xing, B. Sorption of four hydrophobic organic compounds by three chemically distinct polymers: Role of chemical and physical composition. Environ. Sci. Technol. 2012, 46, 7252-7259. [CrossRef] [PubMed]

173. Liu, F.-F.; Liu, G.-Z.; Zhu, Z.-L.; Wang, S.-C.; Zhao, F.-F. Interactions between microplastics and phthalate esters as affected by microplastics characteristics and solution chemistry. Chemosphere 2019, 214, 688-694. [CrossRef]

174. Wang, F.; Shih, K.; Li, X.Y. The partition behavior of perfluorooctanesulfonate (PFOS) and perfluorooctanesulfonamide (FOSA) on microplastics. Chemosphere 2015, 119, 841-847. [CrossRef]

175. Wang, W.; Wang, J. Comparative evaluation of sorption kinetics and isotherms of pyrene onto microplastics. Chemosphere 2018, 193, 567-573. [CrossRef] [PubMed]

176. Wang, W.; Wang, J. Different partition of polycyclic aromatic hydrocarbon on environmental particulates in freshwater: Microplastics in comparison to natural sediment. Ecotoxicol. Environ. Saf. 2018, 147, 648-655. [CrossRef]

177. Hueffer, T.; Hofmann, T. Sorption of non-polar organic compounds by micro-sized plastic particles in aqueous solution. Environ. Pollut. 2016, 214, 194-201. [CrossRef]

178. Pascall, M.A.; Zabik, M.E.; Zabik, M.J.; Hernandez, R.J. Uptake of polychlorinated biphenyls (PCBs) from an aqueous medium by polyethylene, polyvinyl chloride, and polystyrene films. J. Agric. Food Chem. 2005, 53, 164-169. [CrossRef] 
179. Guo, X.; Pang, J.; Chen, S.; Jia, H. Sorption properties of tylosin on four different microplastics. Chemosphere 2018, $209,240-245$. [CrossRef]

180. Velzeboer, I.; Kwadijk, C.J.A.F.; Koelmans, A.A. Strong sorption of PCBs to nanoplastics, microplastics, carbon nanotubes, and fullerenes. Environ. Sci. Technol. 2014, 48, 4869-4876. [CrossRef] [PubMed]

181. Wang, J.; Liu, X.; Liu, G.; Zhang, Z.; Wu, H.; Cui, B.; Bai, J.; Zhang, W. Size effect of polystyrene microplastics on sorption of phenanthrene and nitrobenzene. Ecotoxicol. Environ. Saf. 2019, 173, 331-338. [CrossRef] [PubMed]

182. Wang, Z.; Chen, M.; Zhang, L.; Wang, K.; Yu, X.; Zheng, Z.; Zheng, R. Sorption behaviors of phenanthrene on the microplastics identified in a mariculture farm in Xiangshan Bay, southeastern China. Sci. Total Environ. 2018, 628-629, 1617-1626. [CrossRef]

183. Zhan, Z.; Wang, J.; Peng, J.; Xie, Q.; Huang, Y.; Gao, Y. Sorption of 3,3' ,4,4'-tetrachlorobiphenyl by microplastics: A case study of polypropylene. Mar. Pollut. Bull. 2016, 110, 559-563. [CrossRef] [PubMed]

184. Zhang, X.; Zheng, M.; Yin, X.; Wang, L.; Lou, Y.; Qu, L.; Liu, X.; Zhu, H.; Qiu, Y. Sorption of 3,6-dibromocarbazole and 1,3,6,8tetrabromocarbazole by microplastics. Mar. Pollut. Bull. 2019, 138, 458-463. [CrossRef] [PubMed]

185. Zhang, X.; Zheng, M.; Wang, L.; Lou, Y.; Shi, L.; Jiang, S. Sorption of three synthetic musks by microplastics. Mar. Pollut. Bull. 2018, 126, 606-609. [CrossRef] [PubMed]

186. Koelmans, A.A.; Besseling, E.; Shim, W.J. Nanoplastics in the Aquatic Environment. Critical Review, in Marine Anthropogenic Litter; Bergmann, M., Gutow, L., Klages, M., Eds.; Springer International Publishing: New York, NY, USA, 2015; pp. 325-340.

187. Liu, J.; Ma, Y.; Zhu, D.; Xia, T.; Qi, Y.; Yao, Y.; Guo, X.; Ji, R.; Chen, W. Polystyrene nanoplastics-enhanced contaminant transport: Role of irreversible adsorption in glassy polymeric domain. Environ. Sci. Technol. 2018, 52, 2677-2685. [CrossRef] [PubMed]

188. Jahnke, A.; Arp, H.P.H.; Escher, B.I.; Gewert, B.; Gorokhova, E.; Kühnel, D.; Ogonowski, M.; Potthoff, A.; Rummel, C.; SchmittJansen, M.; et al. Reducing uncertainty and confronting ignorance about the possible impacts of weathering plastic in the marine environment. Environ. Sci. Technol. Lett. 2017, 4, 85-90. [CrossRef]

189. Liu, G.; Zhu, Z.; Yang, Y.; Sun, Y.; Yu, F.; Ma, J. Sorption behavior and mechanism of hydrophilic organic chemicals to virgin and aged microplastics in freshwater and seawater. Environ. Pollut. 2019, 246, 26-33. [CrossRef]

190. Mato, Y.; Isobe, T.; Takada, H.; Kanehiro, H.; Ohtake, C.; Kaminuma, T. Plastic resin pellets as a transport medium for toxic chemicals in the marine environment. Environ. Sci. Technol. 2001, 35, 318-324. [CrossRef]

191. Holmes, L.A.; Turner, A.; Thompson, R.C. Interactions between trace metals and plastic production pellets under estuarine conditions. Mar. Chem. 2014, 167, 25-32. [CrossRef]

192. Hüffer, T.; Weniger, A.-K.; Hofmann, T. Sorption of organic compounds by aged polystyrene microplastic particles. Environ. Pollut. 2018, 236, 218-225. [CrossRef]

193. Liu, P.; Qian, L.; Wang, H.; Zhan, X.; Lu, K.; Gu, C.; Gao, S. New insights into the aging behavior of microplastics accelerated by advanced oxidation processes. Environ. Sci. Technol. 2019, 53, 3579-3588. [CrossRef]

194. Rummel, C.D.; Jahnke, A.; Gorokhova, E.; Kühnel, D.; Schmitt-Jansen, M. Impacts of biofilm formation on the fate and potential effects of microplastic in the aquatic environment. Environ. Sci. Technol. Lett. 2017, 4, 258-267. [CrossRef]

195. Johansen, M.P.; Cresswell, T.; Davis, J.; Howard, D.; Howell, N.R.; Prentice, E. Biofilm-enhanced adsorption of strong and weak cations onto different microplastic sample types: Use of spectroscopy, microscopy and radiotracer methods. Water Res. 2019, 158, 392-400. [CrossRef] [PubMed]

196. Xu, P.; Ge, W.; Chai, C.; Zhang, Y.; Jiang, T.; Xia, B. Sorption of polybrominated diphenyl ethers by microplastics. Mar. Pollut. Bull. 2019, 145, 260-269. [CrossRef] [PubMed]

197. Zhang, H.; Wang, J.; Zhou, B.; Zhou, Y.; Dai, Z.; Zhou, Q.; Christie, P.; Luo, Y. Enhanced adsorption of oxytetracycline to weathered microplastic polystyrene: Kinetics, isotherms and influencing factors. Environ. Pollut. 2018, 243, 1550-1557. [CrossRef] [PubMed]

198. Wu, C.; Zhang, K.; Huang, X.; Liu, J. Sorption of pharmaceuticals and personal care products to polyethylene debris. Environ. Sci. Pollut. Res. 2016, 23, 8819-8826. [CrossRef] [PubMed]

199. Llorca, M.; Schirinzi, G.F.; Martínez, M.; Barceló, D.; Farré, M. Adsorption of perfluoroalkyl substances on microplastics under environmental conditions. Environ. Pollut. 2018, 235, 680-691. [CrossRef]

200. Xu, B.; Liu, F.; Brookes, P.C.; Xu, J. The sorption kinetics and isotherms of sulfamethoxazole with polyethylene microplastics. Mar. Pollut. Bull. 2018, 131, 191-196. [CrossRef]

201. Shen, X.-C.; Li, D.-C.; Sima, X.-F.; Cheng, H.-Y.; Jiang, H. The effects of environmental conditions on the enrichment of antibiotics on microplastics in simulated natural water column. Environ. Res. 2018, 166, 377-383. [CrossRef]

202. Li, R.; Tan, H.; Zhang, L.; Wang, S.; Wang, Y.; Yu, K. The implications of water extractable organic matter (WEOM) on the sorption of typical parent, alkyl and N/O/S-containing polycyclic aromatic hydrocarbons (PAHs) by microplastics. Ecotoxicol. Environ. Saf. 2018, 156, 176-182. [CrossRef]

203. Chen, W.; Ouyang, Z.-Y.; Qian, C.; Yu, H.-Q. Induced structural changes of humic acid by exposure of polystyrene microplastics: A spectroscopic insight. Environ. Pollut. 2018, 233, 1-7. [CrossRef] [PubMed]

204. Zuo, L.-Z.; Li, H.-X.; Lin, L.; Sun, Y.-X.; Diao, Z.-H.; Liu, S.; Zhang, Z.-Y.; Xu, X.-R. Sorption and desorption of phenanthrene on biodegradable poly(butylene adipate co-terephtalate) microplastics. Chemosphere 2019, 215, 25-32. [CrossRef] [PubMed]

205. Bakir, A.; Rowland, S.J.; Thompson, R.C. Enhanced desorption of persistent organic pollutants from microplastics under simulated physiological conditions. Environ. Pollut. 2014, 185, 16-23. [CrossRef] [PubMed]

206. Lee, H.; Lee, H.-J.; Kwon, J.-H. Estimating microplastic-bound intake of hydrophobic organic chemicals by fish using measured desorption rates to artificial gut fluid. Sci. Total Environ. 2019, 651, 162-170. [CrossRef] 